\title{
INTEREST ON JUDGMENTS IN THE FEDERAL COURTS
}

THE function of interest in the judicial process is to compensate a wronged party for the deprivation of the monetary value of his loss from the time of the loss to the payment of a money judgment. ${ }^{1}$ There are two distinct elements of this compensation: interest on the damages and interest on the judgment.? The former is interest covering the period from the date of the loss to the date of ascertainment of damages, and is computed by judge or jury in assessing total damages. ${ }^{3}$ This amount is interest qua damages. Interest on the judgment, however, is interest eo nomine. It is a charge for withholding the total amount of damages once that sum has been determined.t In the federal courts, interest on judgments is authorized by section 1961 of the Judicial Code, which provides: "Interest shall be allowed on any money judgment in a civil case recovered in a district court ... [and] shall be calculated from the date of entry of judgment...."

1. See Young v. Godbe, \&2 U.S. (15 Wall.) 562, 565 (1872); Chesaneake \& Ohio Ry. v. Elk Refining Co., 186 F.2d 30 (4th Cir. 1950); Austrian v. Williams, 103 F. Supp. 64, 118 (S.D.N.Y.), rev'd orr other grounds, 198 F.2d 697 (2d Cir.), ccrl. denticd, 344 U.S. 909 (1952) ; McCorasick, Danjages $\$ 50$ (1935); 1 Sutierland, Dasmages $\S \S 333,334,388,389$ (4th ed., Berryman 1916).

2. "It is believed that there is a distinction between interest on a claim before it is reduced to judgment and interest on a judgment as a judgment." Keen v. Mill-Continent Petroleum Corp., 63 F. Supp. 120, 141 (N.D. Iowa 1945). Sce also Mcore-AfeCor-

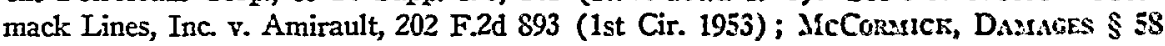
(1935).

3. See, generally, MicCoRarrck, Daxrages $\$ \S 50-59$ (1935); Annot., 36 A.L.R.2d 337 (1954). On the power of a judge to add interest to a verdict where a jury has failed to do so, see Misller v. Robertson, 266 U.S. 243, 257-58 (1924); Annot, 72 A.L.R. 1150 (1931).

4. See, generally, I SUtererland, Dasuages $\$ \S 333,334,388,389$ (4th ed., Berryman 1916) ; Annot, 1 A.L.R.2d 479 (1948). At common law judgments did not bear interest, but interest could be collected as damages in an action in debt to recover a judgment. Tazewell's Ex'r v. Saunders' Ex'r, 54 Va. 354 (1856). See also Perkins v. Fourniquet, 55 U.S. (14 How.) 328, 330 (1852) ; Missouri-Kansas Pipe Line Co. v. Warricls, 25 Del. Ch. 388, 22 A.2d 865 (1941).

Computing interest eo nomine on that part of the judgment comprised of interest qua damages results in compounding interest. It would be possible to avoid this by entering judgment for the amount of the initial loss only and then allowing interest on this sum from the date of the loss until payment. Reed v. Chicago, M. \& St. P. Ry., 25 Fed. \&86 (C.C.N.D. Iowa 1885). See also United States v. 125.71 Acres of Land in Loyalhanna Township, 54 F. Supp. 193 (W.D. Pa. 1944). However, since computation of interest qua damages is an uncertain process which varies among the courts, see Annot., 36 A.L.R.2d 337 (1954), it seems preferable from the standpoint of simplicity to allow interest eo nomine on the judgment after a court has decided what amount of interest gras damages is to be included in the judgment.

5. 28 U.S.C. $\$ 1961$ (1952).

6. Ibid. The full text reads: "Interest shall be allowed on any money judgment in a civil case recovered in a district court. Execution therefor may be levied by the mar- 
While section 1961 would appear to provide for a uniform system of computing interest on judgments, both judicial interpretation of the statute and the actual practice of district court clerks in the absence of judicial instruction have produced a plethora of conflicting and often irrational results. Interest

shall, in any case where, by the law of the State in which such court is held, exccution may be levied for interest on judgments recovered in the courts of the State. Such interest shall be calculated from the date of the entry of the judgment, at the rate allowed by State law." The present version is adapted without substantial change from $\$ 8$ of the Act of Aug. 23, 1842, 5 Stat. 518.

The coverage of the statute is not as broad as the phrase "any money judgment in a civil case" would suggest. Judgments against the United States are excluded, being specifically provided for by 28 U.S.C. $\$ \$ 2411,2516$ (b) (1952). See, e.g., Reed v. Howbert, 77 F.2d 227, 229 (10th Cir. 1935) ; United States v. 125.71 Acres of Land in Loyalhanna Township, 54 F. Supp. 193, 195 (W.D. Pa. 1944). And since most courts do not allow interest on judgments against a state, e.g., Graves v. Saline County, 104 Fed. 61 (7th Cir. 1900) (alternative holding); Yancey v. Highway Commission, 222 N.C. 106, 22 S.E.2d 256 (1942), and cases cited therein, $\S 1961$ would presumably not be applicable to such judgments, although no case presenting this question has yet arisen. But cf. City of Tacoma v. Hoffman, 72 F.2d 721 (9th Cir. 1934). Judgments of the courts of the District of Columbia are excluded from the scope of $\$ 1961$. Washington \& Georgetown R.R. v. Harmon's Adm'r, 147 U.S. 571, 586 (1893). Section 1961 has been held inapplicable also to decrees in equity. E.g., Perkins v. Fourniquet, 55 U.S. (14 How.) 328 (1852) ; Clarke v. Hot Springs Elec. Light \& Power Co., 76 F.2d 918 (10th Cir.), cert. denied, 296 U.S. 624 (1935) ; Hagerman v. Moran, 75 Fed. 97 (9th Cir.), cert. deniel, 159 U.S. 261 (1895). However, three recent cases have applied $\$ 1961$ to such decrees, thereby indicating that the older decisions have been outmoded by the merger of law and equity effected by the Federal Rules of Civil Procedure in 1938. Chemical Bank \& Trust Co. v. Prudence-Bonds Corp., 213 F.2d 443 (2d Cir.), cert. denied, 348 U.S. 856 (1954); Helfer v. Corona Products, 127 F.2d 612, 623 (8th Cir. 1942); Austrian v. Williams, 103 F. Supp. 64, 119 (S.D.N.Y.), rev'd on other grounds, 198 F.2d 697 (2d Cir.), cerl. denied, 344 U.S. 909 (1952). See Fed. R. Civ. P. 1, 2, 54. Decrees in admiralty are also excluded from the scope of $\S 1961$, Moore-McCormack Lines, Inc. v. Amiratilt, 202 F.2d 893 (1st Cir. 1953), and are covered by 41 STAT. 526 (1920), 46 U.S.C. $\$ 743$ (1952). Nor does the statute extend to actions to recover criminal penalties. Pierce v. United States, 225 U.S. 398 (1921) ; United States v. Jacob Schmidt Brewing Co., 254 Fed. 714 (D.N.D. 1918). Whether it covers judgments for civil penalties is in doubt. It was applied to such a judgment in United States v. West Texas Cottonoil Co., 155 F.2d 463 (5th Cir. 1946). However, in Rodgers v. United States, 332 U.S. 371 (1947), the Supreme Court, reviewing only the allowance of interest on penalties for the period prior to judgment, disallowed such interest. In so doing, the Court said it was applying the rules previously applied to criminal fines, $i d$. at 374 , which would suggest no postjudgment interest as well. The narrowness of the issue reviewed, however, seems to indicate that $\S 1961$ does apply to judgments for civil penalties. And finally, a general exclusion doctrine has been developed under which judgments that would not bear interest in a state court will not bear $\$ 1961$ interest in a federal court sitting in that state. People's Bank of Greenville v. Aetna Ins. Co., 76 Fed. 548 (C.C.D.S.C. 1896) (interest on judgment for costs not allowed following South Carolina interest statute). Sce also Rodgers v. United States, supra at 373 n.2; United States v. West Texas Cottonoil Co., supra. Courts have probably developed this rule by interpreting the provision of $\$ 1961$ which merely allows interest, in the light of the clause which states that execution for recovery of interest shall be allowed only if permitted by the law of the state where the federal court sits. 
on judgments is usually computed by district court clerks or by the agreement of counsel, ${ }^{7}$ and in these instances reference is apparently seldom made to the case law in the field. Some of the results, while seemingly reasonable, are directly opposed to the weight of prevailing judicial opinion; others reveal a lack both of reasonableness and uniformity. When the question of interest on judgments has been put to the courts, ${ }^{8}$ the results have produced conflicting interpretations of section 1961.9 Three major problems have arisen: (1) Does

7. This information is based on the results of a questionnaire distributed during December 1954 by the Yale Law Journal to clerks of all the United States District Courts (hereinafter cited as QUESTIONNAIRE). Copies of the questionnaire and responses are on file in the Yale Law Library. Of 90 clerks interrogated, 36 returned complete or nearly complete replies. 16 out of 26 clerks (62\%) report that the question of interest on judgments is never decided by the trial judge. Eight others (31\%) state that the judge decides the problem in less than $10 \%$ of the cases. Two clerks (7\%) report that the judge decides the problem in more than $10 \%$ of the cases, one placing the frequency of the judge's decisions at $20 \%$, the other at $100 \%$. In all those cases where the trial judge does not decide the question of interest on judgments, it is left to the clerk of the court or counsel. As between clerk and counsel, in 13 courts (52\%) counsel decide the problem in most cases; in $S$ courts (32\%) the clerk decides the problem in most cases; and in 4 courts $(16 \%)$ the problem is decided by the clerk as frequently as by counsel.

8. Courts may award interest on judgments in any one of four distinct ways. First, interest may be allowed by the specific authorization of a judgment-interest statute like $\S 1961$. The allowance of interest by this method is the problem with which this comment is concerned. Secondly, where not authorized by statute, interest may be allowed by courts in the exercise of a discretionary power to allow the parties whatever relief is proper in the circumstances of the case. See, e.g., The Conemaugh, 189 U.S. 363 (1903); The Kia Ora, 252 Fed. 507 (4th Cir. 1918). Thirdly, interest may be allowed by the terms of a supersedeas bond. Rule 73(d) of the Federal Rules of Civil Procedure provides that bonds given to stay execution pending appeals shall be conditioned inter alia for the satisfaction of interest if the appeal is dismissed or the judgment affirmed. If the appealed judgment is modified, the bond shall guaranty inter alia "such . . . interest ... as the appellate court may adjudge and award." However, at least one circuit court has apparently refused to view bonds as an independent basis for an interest elaim in affirmance cases, deciding the question instead simply in terms of whether the appellate court has exercised discretion to grant interest. Spruks v. United States Fidelity \& Guaranty Co., 138 F.2d 812 (3d Cir. 1943). Contra, John Hancock Mutual Life Ins. Co. v. Hurley, 151 F.2d 751 (1st Cir. 1945), cert. dented, 327 U.S. 793 (1946) ; MacDonald v. Winfield Corp., 104 F. Supp. 609 (E.D. Pa. 1952). No case has arisen involving interest on bonds where the judgment is modified. Six out of 36 clerlis (17\%) report that supersedeas bonds are always posted during the pendency of an appeal, 16 clerks $(45 \%)$ report bonds are almost always posted, 3 clerks ( $8 \%$ ) report bonds are posted half the time, and 11 . clerks (30\%) report bonds are posted occasionally. QuesTIONNATRE. Finally, interest may be allowed by entering a nunc pro tusse judgment. While the basis of this interest is the prevailing judgment-interest statute, entry of the nume pro tunc judgment regulates the time for which interest is allowed. See Ireland v. Connecticut Co., 112 Conn. 452, 152 Atl. 614 (1930); Barber v. Brisoe, 9 AIont. 341, 23 Pac. 726 (1890). But see Reed v. Howbert, 77 F.2d 227 (10th Cir. 1935); 1 Frenarn:, JUDGMENTS $\$ 131$ (5th ed. 1925).

9. To determine the relevancy of cases construing $\S 1961$, a distinction must be made between cases where an appellate court allow's interest and cases where an appellate court approves allowance of interest by a lower court. An appellate court's allowance of in- 
the taking of an appeal from a district court judgment prevent the application of section 1961, so that no interest runs on the appealed judgment? (2) Should section 1961 be construed to allow interest from the date of verdict instead of judgment in cases where the entry of judgment has been delayed i' (3) Should section 1961 be construed to allow interest from the date of first judgment instead of final judgment where the first judgment has been revised? The second and third questions arise only when the statute is held to apply to the lower court judgment ; and this occurs at least in all cases in which no appeal is taken.

\section{Application of Section 1961}

All courts agree that section 1961 applies to lower court judgments which are not appealed.10 If an appeal is taken, however, there is a conflict as to whether section 1961 applies to whatever judgment is made effective by the appeal. The problems encountered vary depending on the disposition of the lower court's judgment. If that judgment is affirmed, there are three theories concerning the applicability of section 1961. The statute may not apply at all, it may apply to the lower court's affirmed judgment to allow interest from date of that judgment, or it may apply to the lower court's affirmed judgment only for the period of time following affirmance. If the lower court judgment is replaced or revised by a new judgment, the initial question is whether section 1961 applies to the new judgment; if it does, a further issue, to be discussed in a later section, ${ }^{11}$ is whether section 1961 allows interest from the date of the new judgment or from some earlier date.

\section{Affirmance of a Judgment ${ }^{12}$}

Many federal appellate courts have developed a theory which maintains that section 1961 may not be applied to a lower court judgment which has been

terest may be either a discretionary allowance of damages or a conscious effort to allow whatever interest $\S 1961$ authorizes. Since many decisions allowing interest do not even mention $\S 1961$, the basis of the decisions is not clear. It is only when an appellate court reviews a judgment of a lower court and rules on the inclusion or exclusion of interest in that judgment that the court indicates its views on the construction of $\S 1961$. Thus, the significant cases are those in which there have been two appeals-one considering the amount of damages and the second considering the allowance of interest on whatever damages the appellate court's first mandate ordered the lower court to include in its revised judgment.

10. "Interest upon a judgment secured by positive law is as much a part of the judgment as if expressed in it." Blair v. Durham, 139 F.2d 260, 261 (6th Cir. 1943); Amis v. Smith, 41 U.S. (9 Pet.) 301, 311 (1842) (dictum). See alsa United States v. Verdier, 164 U.S. 213, 218 (1898) ; Briggs v. Pennsylvania R.R., 334 U.S. 304, 312 (1948) (dissenting opinion); Moore-McCormack Lines, Inc. v. Amirault, 202 F.2d 893, 895 (1st Cir. 1953) (dictum); National S.S. Co. v. Tugman, 82 Fed. 246 (2d Cir. 1897); 1 Freeman, JUDGMENTS $\$ 89$ (5th ed. 1925).

11. See text at pp. 1032-47 infra.

12. The cases considered in this section involve affirmances of the amount of damages awarded by a lower court. If some aspect of the first judgment other than damages has 
affirmed. This theory derives from the courts' interpretation of another judgment-interest statute, section 1912 of the Judicial Code. ${ }^{13}$ Enacted in 1789, section 1912 gives an appellate court discretion to award "just damages for ... delay" when affirming a lower court judgment.14 Early Supreme Court cases and rules assumed that the word "damages" in this statute covered both punitive damages as a penalty for a frivolous appeal and interest as compensation for the loss of use of the recovery during appeal. ${ }^{15}$ After section 1961 was enacted in 1842, the Supreme Court in Mitchell $\%$. Harmony ${ }^{10}$ held that where a lower court judgment was affirmed, section 1912 applied to the exclusion of section 1961. The taking of an appeal which resulted in affirmance was held to bring the interest problem within the scope of section 1912.17

been modified by the appellate court, the interest question is still treated as if the first judgment had been entirely affirmed. See Bradford v. Commonwealth Trust Co., 98 F.2d 655 (3d Cir. 1938).

13. 28 U.S.C. $\$ 1912$ (1952).

14. Ibid. The full text reads: "Where a judgment is affirmed by the Supreme Court or a court of appeals, the court in its discretion may adjudge to the prevailing party just damages for his delay, and single or double costs." The present version is adapted without substantial change from $\$ 23$ of the Act of Sept. 24, 1789, 1 StAт. 85.

Section 1912 applies also to cases where appeals are dismissed, Slaker v. O'Connor, 278 U.S. 188 (1929) ; Wagner Elec. Mfg. Co. v. Lyndon, 262 U.S. 226 (1923); Deming v. Carlisle Packing Co., 226 U.S. 102 (1912); to non-money judgments, Wagner Elec. MIfg. Co. v. Lyndon, supra; Gibbs v. Diekma, 131 U.S. app. clswuvi (1880); and to decrees in equity as well as at law, Perkins v. Fourniquet, 55 U.S. (14 How.) 328 (1852).

15. The Perseverance, 3 U.S. (3 Dall.) 336 (1797); Sur. CT. RuLes 17, 18, 5 U.S. (1 Cranch) xviii (1803). See Schell v. Cochran, 107 U.S. 625, 628 (18S2): "[I]nterest, for the time a writ of error is pending, is really damages for delay."

16. 54 U.S. (14 How.) 115 (1851).

17. Ibid. And see Perkins v. Fourniquet, 55 U.S. (14 How.) 323 (1852), reviewing and approving the Mitchell decision. The principal reason given in Perliss to explain why $\S 1912$ applied instead of $\S 1961$ was that the effective judgment in the case was a judgment of the Supreme Court to which $\S 1961$. does not apply. Id. at 331 .

This notion that an appellate court's judgment of affirmance itself becomes the effective judgment instead of merely being an order to leave in effect the lower court judgment has subsequently found support only in cases involving the lower court's jurisdiction, after affirmance, to hear a motion for a bill of review or for a new trial. See, e.g., Flowers v. United States, 86 F.2d 79, 80 (8th Cir. 1936): "It will be noted that this court affirmed the judgment of the lower court. This affirmance in effect made the judgment of the lower court the judgment of this court." See also Obear-Nester Glass Co. v. Hartford Empire Co., 61 F.2d 31, 34 (8th Cir. 1932); American Foundry Equipment Co. v. Wadsworth, 290 Fed. 195, 196 (Sth Cir. 1923). This same language has been used where the appellate court orders entry of a new judgment. See, c.g., United States $v$. Illinois Surety Co., 226 Fed. 653, 664 (7th Cir. 1915); Meyer v. Goldsmith, 196 S.W. 745, 746 (Mo. 1917), writ of error dismissed, 246 U.S. 678 (1918) : "[T] he judgment ... was in effect and fact a judgment of the Court of Appeals."

But this theory has been rejected by many courts. See, e.g., Steinbach v. Stewart, 78 U.S. (11 Wall) $566,574-75$ (1870) : "The judgment upon the appeal was . . that the decree of the District Court, in so far as it confirmed the original grant, be itself affirmed. [I]t left that decree in full force to all its extent." See also State v. Krug, 94 Ind. 36 fo (1883). Since courts disagree as to whether an affirmed judgment is a lower court or an appel- 
Under this statute the allowance of interest has been held to depencl on the discretion of the appellate court. ${ }^{18}$ Moreover, section 1912 has consistently been construed to mean that an appellate court's mandate which is silent on the subject of interest indicates a refusal to exercise this discretion and hence constitutes a denial of interest. ${ }^{10}$ Thus, under the Mitchell theory, a lower court's application of section 1961 to allow interest on an affirmed judgment would violate a silent mandate's denial of interest. ${ }^{20}$ Nor may a district court justify application of section 1961 by reference to the court rules, adopted by all appellate tribunals, which specifically order that interest on affirmed judgments be computed from the date of the lower court judgment to payment. ${ }^{21}$

late court judgment, it would seem senseless to make allowance of interest depend on this irrelevant criterion. Clearly interest should be governed by a uniform rule. This can be accomplished through $\S 1961$ in spite of the conflict as to which court's judgment is involved. The statute makes interest mandatory on judgments "recovered" in the district courts, not on district court judgments. And even if the judgment of the lower court is viewed as the judgment of the affirming court, the final judgment may still be regarded as one recovered in the lower court, regardless of "whose" judgment it is.

18. In re Washington \& Georgetown R.R., 140 U.S. 91 (1891) ; Perkins v. Fourniquet, 55 U.S. (14 How.) 328 (1852) ; Boyce v. Grundy, 34 U.S. (9 Pet.) 273 (1835); The Santa Maria, 23 U.S. (10 Wheat.) 431 (1825); Washington \& Georgetown R.R. v. Harmon's Adm'r, 147 U.S. 571, 589 (1893) (dictum); Clarke v. Hot Springs Elec. Light \& Power Co., 76 F.2d 918 (10th Cir.), cert. denied, 296 U.S. 624 (1935); Green v. Chicago, S. \& C.R.R., 49 Fed. 907 (6th Cir. 1892) ; cf. United States v. United States District Courrt, 272 Fed. 611 (9th Cir. 1921). See also 1 Surmerdand, Dansages 1254-56 (4th ed., Berryman 1916).

19. E.g., In re Washington \& Georgetown R.R., 140 U.S. 91 (1891) ; Boyce v. Grundy, 34 U.S. (9 Pet.) 273 (1835) ; The Santa Maria, 23 U.S. (10 Wheat.) 431 (1825); Clarks v. Hot Springs Elec. Light \& Power Co., 76 F.2d 918 (10th Cir.), cert. denied, 296 U.S. 624 (1935) ; Hagerman v. Moran, 75 Fed. 97 (9th Cir.), cert. denied, 159 U.S. 261 (1895); Green v. Chicago, S. \& C.R.R., 49 Fed. 907 (6th Cir. 1892). See 1 Sutherland, Danaces 1254-56 (4th ed., Berryman 1.916).

While the Supreme Court has held that affirmance would not continue interest merely authorized by a local judgment-interest statute, it has suggested that the restlt might be different if the lower court judgment which was affirmed had carried the authorized interest in express terms. In re Washington \& Georgetown R.R., supra at 95, 97. Sec also Green v. Chicago, S. \& C.R.R., supra at 909.

20. See Mitchell v. Harmony, 54 U.S. (13 How.) 115, 147-50 (1851); Perkins v. Fourniquet, 55 U.S. (14 How.) 328, 331 (1852) (dictum); In $r c$ Washington \& Georgctown R.R., 140 U.S. 91 (1891) ; cf. Briggs v. Pennsylvania R.R., 334 U.S. 304 (1948); Boyce v. Grundy, 34 U.S. (9 Pet.) 273 (1835) ; Clarke v. Hot Springs Elec. Light \& Power Co., 76 F.2d 918 (10th Cir.), cert. denied, 296 U.S. 624 (1935).

21. Sur. CT. RuLE 56 reads as follows:

"1. Where judgments for the payment of money are affirmed, and interest is properly allowable, it shall be calculated from the date of the judgment below until the same is paid, at the same rate that similar judgments bear interest in the courts of the State where such judgment was rendered.

"2. In all cases where an appeal delays proceedings on the judgment of the lower court, and appears to have been sued out merely for delay, damages at a rate not exceeding 10 per cent., in addition to interest, may be awarded upon the amount of the judigment.

“3. In cases in admiralty, damages and interest may be allowed only if specially directed by the court. 
These rules are held to derive from section 1912.20 Therefore, they are to be used only at the discretion of the affirming court, and do not operate unless explicitly invoked. ${ }^{23}$

There is substantial recent authority, however, for the proposition that section 1961 does apply to allow interest on a lower court's affirmed judgment from the date of its entry. In rejecting the notion that interest on an affirmed judgment is reserved to the discretion of the affirming court by section 1912, this view proceeds on the simple premise that interest attaches automatically to the original judgment by force of section $1961 . .^{21}$ Thus an order by the appellate court that the judgment be affirmed is to be interpreted by the lower court as a direction to continue in effect an interest-bearing judgment. ${ }^{25}$ When the lower court allows interest from the date of the

"4. Where a petition for writ of certiorari has been filed, and there appears to be no ground for granting such a writ, the court may, in appropriate cases, adjudge to the respondent reasonable damages for his delay."

All federal appellate courts have substantially similar rules. 1Sr CIR. RunE 32; 2D CIs Rule 26; 3D Crr. Rule 34; 4tr CIR. Rule 20; 5th CIR Rule 30; 6rir Cir. Rule 27; 7tu Cir Rule 23; 8Th CIR Rule 21 ; 9Th Cir. Rule 24; 10TH CIR. Rule 25; D.C. Cilt. Rule 23.

Rules of the 7th and D.C. circuits include only para. 2 of Sur. CT. RuLE 56.

The qualification in para. 1 of Str. Cт. Rune 56 that "interest is properly alluwalle" is included in the rules of the 1st, 3d, 4th, and Sth circuits. This phrase does not seem to make allowance of interest discretionary, however, when compared with para. 3 of Sur. $C_{\text {. }}$. RULE 56, which implies that interest shall be allowed in all cases other than admiralty even if not specially directed by the court.

The following phrase in 6TH CIR. RuLE 27 evidences the elearest attempt to give seliexecuting effect to an interest rule: "In all cases to which this clause of the rule applies, the mandate shall be taken to direct the allowance of such interest."

22. Perkins v. Fourniquet, 55 U.S. (14 How.) $32 S$ (1852) ; West Wis. Ry. v. Foley; 94 U.S. 100 (1876). See also Consolidated Rubber Tire Co. v. Diamond Rubber Co., 232 Fed. 508 (S.D.N.Y. 1916).

23. In re Washington \& Georgetown R.R., 140 U.S. 91, 96 (1891); Boyce v. Grundy, 34 U.S. (9 Pet) 273 (1835) ; Washington \& Georgetown R.R. v. Harmon's Adm'r, 147 U.S. 571, 588-89 (1893) (dictum); Hagerman v. Moran, 75 Fed. 97 (9th Cir.), cert. denied, 159 U.S. 261 (1895) ; Green v. Chicago, S. \& C.R.R. 49 Fed. 907 (6th Cir. 1892) ; DeWitt v. United States, 298 Fed. 182 (D. Colo. 1923); Consolidated Rubber Tire Co. v. Diamond Rubber Co., 232 Fed. 50 (S.D.N.Y. 1916). Contra, Huntley v. Southern Oregon Sales, Inc, 104 F.2d 153 (9th Cir. 1939); Anglin \& Stevenson v. United States, 160 F.2d 670, 672 (10th Cir.), cert. denied, 331 U.S. 834 (1947) (dictum) ; Louisville \& Nashville R.R. v. Melton, $146 \mathrm{Ky} .242,142$ S.W. 382 (1912); cf. Chemical Bank \& Trust Co. v. PrudenceBonds Corp., 213 F.2d 443 (2d Cir.), cert. denied, 348 U.S. 856 (1954).

Effort has also been made to use the following phrase, included in all mandates, as a basis for the lower court's use of $\S 1961$ even when a mandate is silent as to interest: "... [F] [urther proceedings [shall] be had ... as according to ... the laws of the United States ought to be had." The Supreme Court has rejected this theory. Gaines v. Rugg, 148 U.S. 228, 243 (1S92) ; In re Washington \& Georgetown R.R., supra; Boyce v. Grundy, supra.

24. See cases cited note 10 supra.

25. Blair v. Durham, 139 F.2d 260 (6th Cir. 1943). See also Eugene R. Smith Co. v. Russek, 212 F.2d 338 (5th Cir. 1954) ; Bradford v. Commonwealth Trust Co., 93 F.2d 655 (3d Cir. 1938) (by implication); City of Tacoma v. Hoffman, 72 F.2d 721 (9th Cir. 1934) 
appealed judgment, therefore, it is following the mandate rather than enlarging upon it. ${ }^{26}$ Under this theory, section 1912 is viewed as giving an appellate court discretion to award damages for the delay resulting from an appeal, irrespective of section 1961 interest. $^{27}$ This analysis has the approval of at least four circuit courts of appeal. ${ }^{28}$ Moreover, thirty-five of the thirty-six district court clerks who responded to a questionnaire reported that they allow interest on an affirmed judgment even when, as is usually the case, the mandate of affirmance makes no mention of interest. ${ }^{20}$

Section 1961 could be interpreted to apply to affirmed lower court judgments only for the time from affirmance to payment. This view is suggested by the wording of section 1912. Under this theory, the "delay" for which section 1912 allows an affirming court to award interest is limited to the period from lower court judgment to affirmance, which is the only period during

(same) ; St. Petersburg Advertising Co. v. American Motorsign Co., 25 F.2d 397 (5th Cir. 1928) ; Myers v. Velasquez, 16 F.2d 111. (5th Cir. 1926) (by implication); United States v. Henke Constr. Co., 68 F. Supp. 3, 5 (W.D. Mo. 1946) (dictum).

26. See cases cited note 25 supra.

State courts uniformly agree that affirmance continues whatever interest is allowed by law on the lower court judgment. E.g., Kinney v. Pollak, 225 Ala. 229, 142 So. 390 (1932); Seremitis v. Cook, 327 Mich. 450, 42 N.W.2d 135 (1950); In rc Thomasson's Estate, 192 S.W.2d 867 (Mo. 1946) ; M. E. Trapp Associated v. Tankersley, 206 Okla. 118, 240 P.2d 1091 (1951) ; Wolfgang v. Henry Thiele Catering Co., 141 Ore. 280, 17 P.2d 313 (1932). The Supreme Court has impliedly approved this result where the affirmance was ordered by an appellate court of the District of Columbia. Washington \& Georgetown R.R. v. Harmon's Adm'r, 147 U.S. 571 (1893). Reviewing the allowance of interest by a District of Columbia lower court on a judgment which had been affirmed by a District of Columbia appeliate court, the Supreme Court examined the question of whether or not lower court judgments in tort in the District of Columbia bear interest. Concluding that they do not, the Supreme Court held that affirmance by the D.C. appellate court therefore continued no interest. Implicit in this reasoning is the assumption that affirmance by the D.C. appellate court would have continued interest if the D.C. lower court judgment had carricd interest. This can be seen by comparing this case with the earlier case of $I n r c$ Washington \& Georgetown R.R., 140 U.S. 91 (1891), where the Supreme Court was reviewing the effect of its own affirmance of a D.C. judgment. The court there refused to consider whether D.C. judgments in tort bear interest, holding that affirmance by the Supreme Court continues no interest uniess the Supreme Court expressly authorizes it.

27. Blair v. Durham, 139 F.2d 260 (6th Cir. 1943).

28. Blair v. Durham, 139 F.2d 260 (6th Cir. 1943) ; Bradford v. Commonwealth Trust Co., 98 F.2d 655 (3d Cir. 1938) ; City of Tacoma v. Hoffman, 72 F.2d 721 (9th Cir. 1934); St. Petersburg Advertising Co. v. American Motorsign Co., 25 F.2d 397 (5th Cir. 1928); Myers v. Velasquez, 16 F.2d 111 (5th Cir. 1926). In Blair the appellate court approved the lower court's allowance of interest on a judgment which had been entered in response to a mandate which made no mention of interest. In St. Petcrsburg Advertising Co. the appeliate court, when affirming a lower court judgment, specifically refused to add interest to its mandate, holding that interest was allowed by $\S 1961$. The other three decisions might be distinguished on the ground that interest was mentioned in the lower court judgment, but the opinions imply that this fact was not determinative.

- 29. QUESTIONNAIRE. 20 out of 29 clerks $(69 \%)$ report that mandates omit any mention of interest in $100 \%$ of the cases. Eight additional clerks (28\%) report this result occurs in at least $95 \%$ of the cases. 
which appeal actually causes delay. ${ }^{30}$ Thus, an affirming court's refusal to allow section 1912 interest means only that no interest shall be allowed for this period. After affirmance, section 1961 would operate automatically to allow interest from affirmance to payment. ${ }^{31}$

Of these three theories, the one which applies section 1961 to an affirmed lower court judgment from the date of that judgment to payment is clearly preferable. For resolving the apparent statutory conflict between sections 1961 and 1912, the theory of complete application of section 1961 is unquestionably superior to the notion of non-application of the statute, and is at least as reasonable as the view favoring partial application. Furthermore, analysis of the relevant policy considerations reveals that, of the three theories, complete application is the one which achieves the most desirable results.

While Congress did not indicate which of the three theories was to reconcile sections 1912 and $1961,{ }^{32}$ a fair reading of both statutes indicates that non-application of section 1961 is the least successful method of harmonizing the apparent statutory discord. It is most unlikely that Congress would enact a statute which makes interest mandatory on a lower court judgment which is not appealed, without at the same time repudiating the theory that section 1912 denies interest on an affirmed lower court judgment whenever the affirming court fails to add the words "with interest." This should have been obvious to the Supreme Court when it decided the Mitchcll case. At that time the Supreme Court rule implementing section 1912 allowed interest only until date of affirmance. ${ }^{33}$ Therefore, under the non-application theory, interest on a judgment which was not appealed ran by force of section 1961 until payment, but if that judgment was appealed and affirmed, the most plaintiff could receive was discretionary interest up to affirmance, and no interest at all thereafter. ${ }^{34}$

The theories of partial and complete application both reach reasonable resolutions of the statutory conflict. Under partial application of section 1961,

30. For the proposition that $\S 1912$ covers only the period from lower court judgment to affirmance, see Blair v. Durham, 139 F.2d 260 (6th Cir. 1943). The early Supreme Court rules limited the statute to this interval. See note 33 infra and accompanying test.

31. Since under this theory $\S 1912$ is operative only for the period of actual delay, $\S 1961$ is still effective from lower court judgment up to the date defendant files his notice of appeal.

32. The statute was approved by the Senate unanimously without discussion. Co:ac. GioBE, 27th Cong., 2d Sess. 723 (1842). No committee report indicating congressional intent on the subject is available.

33. Sup. CT. Rule 20, 8 U.S. (4 Cranch) 1 (1807).

34. Mitchell v. Harmony. 54 U.S. (13 How.) 115, 147-50 (1851); Perkins v. Fuurniquet, 55 U.S. (15 How.) 328, 332 (1852) (dictum). Instead of re-examining the theury of 1 Iitchell, the Supreme Court simply changed the rule to allow interest until payment. Sup. CT. Rule 62, 54 U.S. (13 How.) v (1851). 
section 1912 still gives an appellate court discretion to award interest from lower court judgment to affirmance, which is the period to which the latter statute in terms pertains. Complete application of section 1961, on the other hand, limits section 1912 by replacing the affirming court's discretionary power to grant interest with section 1961's mandatory allowance of interest. ${ }^{36}$ But section 1912 would still give an appellate court discretion to award punitive damages as a penalty for a frivolous appeal. ${ }^{36}$ Under this view, each statute has a distinct as well as a useful function.

The complete application theory is the only one which assures that interest will fulfill its proper function in the judicial process. Interest is a mechanism which aids in the function of the entire process-namely, to render a wronged party "whole." Since the lower court judgment plus the interest qua damages which is computed up to that time render the plaintiff whole as of the date of that judgment, ${ }^{37}$ interest must be allowed on this aggregate sum from judgment until payment to render the plaintiff whole at date of payment. The only plausible reason for giving an affirming court discretion to grant or withhold interest for any portion of this time is to provide the court with an opportunity to enforce the rule that an unsuccessful appeal by a prevailing party stops the running of interest. The current validity of this rule is doubtful. ${ }^{38}$ The rule is not required by either section 1912 or 1961, nor is it supported by common sense. If a defendant wants to stop the running of interest while his successful adversary is appealing for a larger judgment, he can

35. In developing the theory that $\S 1912$ excludes $\$ 1961$ from affirmed judgments, the Supreme Court specifically rejected the idea that $\$ 1961$ was intended to amend $\$ 1912$. Perkins v. Fourniquet, 55 U.S. (14 How.) 328, 330 (1852).

36. "[Section 1912] gives us the only power we have to prevent frivolous appeals...." Amory v. Amory, 91 U.S. 356, 357 (1875). And see West Wis. Ry. v. Foley, 94 U.S. 100 (1876).

37. Interest qua damages is computed up to date of judgment where there is no delay from verdict to judgment. When such delay occurs, however, the computation of intercst qua damages varies among the several courts. See note 3 supra; note 67 infra and accompanying text.

38. This rule originated at common law, e.g., Bull v. Ketchum, 2 Denio 188 (N.Y. 1846), and has since found support primarily in admiralty cases, c.g., The Scotland, 118 U.S. 507, 520 (1886) ; Lauro v. United States, 168 F.2d 714 (2d Cir. 1948). Relying on admiralty cases, the Supreme Court in Bates v. Dresser, 251 U.S. 524 (1920), applied the rule to stop interest on a decree in equity. Since $\$ 1961$ was then thought inapplicable to equity decrees, Bates did not decide whether the rule is valid in cases governed by the judgment-interest statute. Subsequently two other federal courts acknowledged the rule also in cases to which $\S 1961$. did not apply. Both courts, however, explicitly pointed out the inapplicability of the statute, which implies a belief that had $\S 1961$ been available, the rule would have been ignored. Clarke v. Hot Springs Elec. Light \& Power Co., 76 F.2d 918 (10th Cir.), cert! denied, 296 U.S. 624 (1935) ; United States v. 125.71 Acres of Land in Loyalhanna Township, 54 F. Supp. 193 (W.D. Pa. 1944). Two decisions have considered the rule in cases where $\$ 1961$ applies. Zurich Gen. Acc. \& Liab. Co. v. Mid-Contincnt Petroleum Co., 43 F.2d 358 (10th Cir. 1930); United States v. Henke Constr. Co., 68 F. Supp. 3 (W.D. Mo. 1946). In $Z$ urich defendant tendered the amount due but subsequently withdrew the tender and contested liability. The court said the rule of Bates v. Dresser, 
tender to plaintiff the amount of the lower court judgment admittedly due.so As long as the defendant retains the amount of the lower court judgment, he is benefiting from the use of money which by his failure to appeal he concedes is due the plaintiff. Thus, since there is no reason for an appellate court to have discretion to allow or withhold interest for any period of time, section 1961 should be completely applied to affirmed judgments to make the plaintiff whole. ${ }^{40}$

\section{New Judgments}

When an appellate court orders a lower court judgment revised or replaced with a new one, there is no apparent reason why section 1961 should not apply to the lower court's new judgment. While there is a problem as to whether section 1961 should be construed to allow interest for the period from the lower court's original judgment to the new judgment, a question to be discussed later, ${ }^{41}$ the language of the statute clearly indicates that it should apply to the new judgment, and that it should allow interest at least from the

supra, would have applied if defendant had been prevented from paying the judgment. But the court held that defendant could not benefit from the rule since he had withdrawn his tender. Henke held that the validity of the rule depends on the practice of the state in which the fedcral court sits. State rules on this problem are cited at note 146 infro.

39. See, e.g., Broward County Port Authority v. Arundel Corp., 206 F.2d 220 (5th Cir. 1953) ; Zurich Gen. Acc. \& Liab. Co. v. Mid-Continent Petroleum Co., 43 F.2d 358 (10th Cir. 1930) (by implication) ; Schwarz v. Harris, 209 Fed. 1000, 1001 (D. Ore. 1913) (dictum).

Courts which acknowledge the rule that appeal by the prevailing party stops interest have argued that defendant was prevented from satisfying the judgment by plaintiff's appeal. See, e.g., United States т. 125.71 Acres of Land in Loyalhanna Township, 54 F. Supp. 193 (W.D. Pa. 1944). A California court has correctly rejected this argument, holding that interest can be stopped at any time by tender. Ferrea v. Tubbs, 125 Cal. 687, 58 Pac. 308 (1899). See also March v. Portsmouth \& Concord R.R., 19 N.H. 372 (1849).

40. Even if it is accepted that $\$ 1912$ makes the allowance of interest on an affirmed judgment depend on the use of discretion by the affirming court, these courts should be held to have permanently invoked their discretionary power by the adoption of rules which declare that interest shall run on affirmed judgments. See note 21 sipra. These rules order this result whether or not the affirming court adds the words "with interest." Nevertheless, most decisions have held that these rules do not allow interest unless the affirming court specifically applies its own rule. See cases cited note 23 supro. Commenting on these opinions, Judge Learned Hand, sitting as district court judge, said: "I confess that, independent of authority, I should have thought that under this rule every mandate from the Circuit Court of Appeals ought to be interpreted as awarding interest unless the contrary was stated ... [E] [Ether the court [deciding In re Washington \& Georgetown R.R, 140 U.S. 91 (1891)] supposed the rule did not operate ex proprio vigori, or they overloolied the rule altogether. I must assume the former." Consolidated Rubber Tire Co. v. Diamond Rubber Tire Co., 232 Fed. 508, 509 (S.D.N.Y. 1916).

The draftsmen of the rules of the sixth circuit were apparently aware of this problem and attempted to solve it by giving self-executing effect to the interest rule of that circuit. See note 21 supra.

41. See text at pp. 1032-47 infra. 
date of that judgment to payment. ${ }^{42}$ It would seem that an appellate court, absent statutory authority, has no discretion which precludes the application of section 1961 to new judgments. No such statutory authority exists. Section 1912 is not available in those cases where new judgments result from the partial affirmance of lower court judgments, ${ }^{43}$ since the statute pertains only to those judgments which are totally affirmed, ${ }^{44}$ and there is no similar statute governing either partial affirmances or other new judgments.

Nevertheless, the Supreme Court in Briggs v. Pennsylvania R.R.45 a 5to-4 decision, adopted a rationale which logically leads to the conclusion that section 1961 may not be applied to new judgments. In Briggs a district court had entered a judgment for plaintiff in response to a circuit court's mandate reversing a defendant's judgment n.o.v. ${ }^{\mathbf{4 0}}$ The district court applied section 1961 to the new judgment, and construed that statute to allow interest from verdict. ${ }^{47}$ On reappeal, the circuit court approved the lower court's decision that section 1961 was applicable, but interpreted the statute to allow interest only from date of new judgment to payment. ${ }^{48}$ Upon granting certiorari solely to decide the correctness of the circuit court's denial of interest from verdict to new judgment, ${ }^{49}$ the Supreme Court agreed with the result reached by the circuit court. ${ }^{50}$ However, the Court deemed it unnecessary to decide whether section 1961 should be construed to allow interest from verdict to new judgment, but instead held that the trial court had no right even to apply the statute. The Court argued that because the circuit court's mandate had made no provision for interest, the district court could not grant interest."H Implicit in this reasoning is the assumption that an appellate court has a discretionary authority which displaces section 1961 in the period from verdict to new judgment. ${ }^{52}$ This theory would seem just as valid for the interval from

42. See text of statute at note 6 stipra.

43. Decisions holding that $\S 1912$ makes interest discretionary with the affirming court have been rejected as authority in cases where the judgment has not been completely affirmed. Dresser v. Bates, 250 Fed. 525 (1st Cir. 1918), rev'd on other groulnds, 251 U.S. 524 (1920) (partial affirmance); Metcalf v. City of Watertown, 68 Fed. 859, 863-64 (7th Cir. 1895) (reversal of judgment n.o.v.); The Grapeshot, 10 Fed. Cas. 987, No. 5,703 (C.C.D. La. 1874) (partial affirmance).

44. See text of statute at note 14 supra.

45. 334 U.S. 304 (1948).

46. Briggs v. Pennsylvania R.R., 164 F.2d 21, 22 (2d Cir. 1947).

47. Ibid.

48. Briggs v. Pennsylvania R.R., 164 F.2d 21 (2d Cir. 1947) (alternative holding), aff'd without consideration of this point, 334 U.S. 304 (1948).

49. See Briggs v. Pennsylvania R.R., 334 U.S. 304, $307-09$ (1948) (dissenting opinion). See also Brief in Support of Petition for Certiorari, p. 3, Briggs v. Pennsylvania R.R., 334 U.S. 304 (1.948).

50. Briggs v. Pennsylvania R.R., 334 U.S. 304 (1948).

51. "The [second circuit's first] mandate made no provision for such interest [from verdict to judgment] and the trial court had no power to enter judgment for an amount different than directed." Id. at 306.

52. Since the Supreme Court specifically objected to the trial court's entry of judit:ment for "an amount different than directed," see note 51 supra, it might be thought that 
judgment to payment, since the mandate through which the appellate court exercises its discretion controls the entire disposition of the case. ${ }^{53}$ Thus, the Supreme Court's rationale, which led it to the holding that section 1961 does not apply from verdict to new judgment, indicates that the statute does not apply at all to new judgments which replace judgments n.o.v. Furthermore, whatever discretion an appellate court has to bar application of section 1961 to these judgments would logically effect the same result with regard to all other new judgments, since the controlling authority of the mandate is the same in all these cases. ${ }^{54}$

Reason and authority are clearly opposed to the position that section 1901 does not apply to a new judgment. The Court in Briggs clearly erred in assuming that an appellate court's discretion, and not section 1961, governs the allowance of interest on new judgments. The Court failed to realize that there is no statutory basis for this discretion. ${ }^{55}$ The cases upon which the Briggs majority relied involved affirmances, and hence the courts deciding them could rest upon section $1912 ;^{56}$ but neither these decisions nor that statute have any bearing on new judgments. Furthermore, Briggs seems to be completely at odds with earlier closely analogous Supreme Court decisions. ${ }^{57}$ In each of these cases, the Supreme Court approved allowance of interest by a lower court on a new judgment entered after receipt of an appellate court's mandate which made no mention of interest. It based these decisions on a discretionary power of the lower court to allow interest. ${ }^{\text {ss }}$ If a lower court can allow interest on a new judgment by the use of discretion, it obviously should be able to allow interest by force of a mandatory statute. ${ }^{\text {s }}$ Moreover, the potential extension of the Briggs theory beyond judgments which replace judgments n.o.v. to all new judgments has recently been rejected by the Second Circuit. ${ }^{60}$ And a poll of district court clerks indicates

the lower court would have been correct to enter judgment for the exact amount ordered and then allow interest on this amount from date of verdict. This explanation of Briggs is most doubtful, since the Supreme Court had previously said that interest upon a judgment secured by positive law is as much a part of the judgment as if expressed in it. Amis v. Smith, 41 U.S. (16 Pet.) 301, 311 (1842) (dictum).

53. See 28 U.S.C. $\$ 2106$ (1952); 14 Cyclopedia of Federal. Procedure $\$ \S 69.01$, $69.02,69.03$ (3d ed. 1952).

54. Ibid.

55. See text at notes $43-44$ supra.

56. See the dissent's analysis of these cases, Briggs v. Pennsylvania R.R., 334 U.S. 304,311 n.1.1 (1948).

57. De La Rama v. De La Rama, 241 U.S. 154 (1916) ; Ex rarte Republic of Colombia, 195 U.S. 604 (1904) ; Kneeland v. American Lean \& Trust Co., 138 C.S. 549 (1841).

58. Ibid. While Colombia and Knecland may be explained on the basis of a partial affirmance which in effect sanctioned lower court allowance of interest, the result in $D_{c} L_{0}$ Ramia was attributed solely to the lower court's discretion.

59. Section 1961 was not cited as authority for interest in these decisions probably because the cases involved equity decrees to which the statute was thought to have no application. See' note 6 supra.

60. Chemical Bank \& Trust Co. v. Prudence-Bonds Corp., 213 F.2d 443 (2d Cir.), cert. denied, 348 U.S. 856 (1954). For a discussion of this case, see nate 107 infra. 
that in practice interest is allowed on new judgments, although the starting date of interest varies. ${ }^{61}$ The application of section 1961 to new judgments is clearly ordered by its terms, and is essential to insure that interest on judgments fulfills its proper function-to compensate the plaintiff completely for the delay in receiving his recovery. ${ }^{\mathbf{6 2}}$

\section{From Verdict to Judgment}

Delay between verdict and judgment, which is generally caused by consideration of motions, occurs most often in cases which are not appealed. In such cases, section 1961 clearly applies, ${ }^{63}$ and consequently the question arises whether it should be construed to allow interest for the period of this delay. Where a delayed judgment is appealed and affirmed, this same problem of interpretation will be presented in those circuits which follow the theory of "complete application" of section 1961.64 However, where the delay between verdict and new judgment is occasioned by an appellate court's reversal of a judgment n.o.v., the Briggs rule makes it unnecessary to decide whether section 1961 covers the period of delay, for the lower court cannot use the statute at all. ${ }^{65}$ But the patently erroneous reasoning of Briggs affords substantial grounds for believing that the rule of that case will be reversed when the Supreme Court again considers it. ${ }^{66}$ Therefore, the following discussion of the proper interpretation of section 1961 will include cases like Briggs. Of course, whether the delay from verdict to judgment is cattsed in the trial court or on appeal, the problem of allowing interest on a judgment for this interval does not arise where interest qua damages is computed up to judgment. But generally this type of interest is assessed only until verdict, ${ }^{07}$ and hence does not compensate for the delay from that date to judgment.

Even if section 1961 is construed not to allow pre-judgment interest, such

61. QUESTIONNAIRE. Where the new judgment results from the reversal of defendant's successful motion for judgment n.o.v., as in Briggs v. Pennsylvania R.R., 334 U.S. 304 (1948), 27 out of 29 clerks (93\%) allow interest. 12 clerks (41\%) allow it from the date of the first (erroneous) judgment; 3 clerks (10\%) from the date of the appellate court's mandate; 3 clerks $(10 \%)$ from the date of entry in the lower court docket of the appellate court's decree; and 9 clerks (31\%) from the date of the lower court's final judgment. For results on other types of new judgments, see note 127 infra.

62. See text at note 37 sipra.

63. See note 10 sitpra and accompanying text.

64. See text at notes 24-29 supra.

65. See text at notes 45-53 sipra.

66. See text at notes 55-59 sipra.

67. See, e.g., Wright v. Harlan Fuel Co., 214 Ky. 602, 603, 283 S.W. 944, 945 (1926) : "[T] he verdict of the jury fixing the damages includes the intercst up to the time the vordict is rendered. For the verdict of the jury is a finding of the damages to which the plaintiff is entitled at that date"; Hill v. Wilson, 123 Ore. 193, 261 Pac. 422 (1928); St. Latis \& S.F. Ry. v. Ewing, 145 S.W. 1028 (Tex. Civ. App. 1912). For an example of comptutiug interest qua damages up to entry of judgment, see Stentor Elec. Mfg. Co. v. Klaxon Co., 125 F.2d 820 (3d Cir.), cert. denied, 316 U.S. 685 (1942), affirming 30 F. Supp. 425 (D. Del. 1939). See, generally, Annot., 72 A.L.R. 1150 (1931). 
interest may be awarded by authority of state law. ${ }^{63}$ The federal courts are in conflict as to the construction of section 1961, and state law on allowance of pre-judgment interest varies not only among the several states but even within many of them.

\section{Construction of Section 1961}

The alternative views on whether section 1961 allows pre-judgment interest are exemplified on the one hand by the second circuit's opinion in Briggs $v$. Pennsylvania R.R., ${ }^{69}$ and on the other by the fifth circuit's decision in Louisiana \& Arkansas Ry. v. Pratt. ${ }^{70}$ Both cases involved delay between verdict and judgment caused by the reversal of defendant's initially successful motion for judgment n.o.v.

The second circuit's decision in Briggs refuses interest during the delay, arguing that until the plaintiff's judgment is entered, he is not "entitled" to his recovery and therefore has no right to interest on that recovery; he may simply exercise his right of appeal. ${ }^{71}$ It is only when he secures his judgment at the conclusion of the appellate process that plaintiff becomes entitled to his recovery, plus interest from the date the judgment actually became due. ${ }^{72}$ The general practice of district court clerks conforms to the Briggs rule. ${ }^{73}$

68. Allowance of interest from verdict to judgment has also been based on the theory that the defendant was at fault in delaying entry of judgment by his unsuccessful motion for judgment n.o.v. or for a new trial. Gunther v. Liverpool, London \& Globe Ins. Co., 10 Fed. 830 (C.C.E.D.N.Y. 18S2), rev'd on other grostnds, 116 U.S. 113 (1885); Gibson v. Cincinnati Enquirer, 10 Fed. Cas. 309, No. 5,391 (C.C.S.D. Ohio 1877); Dowell v. Griswold, 7 Fed. Cas. 995, No. 4,040 (C.C.D. Ore. 1877).

69. 164 F.2d 21 (2d Cir. 1947) (alternative holding), aff'd without considcration of this point, 334 U.S. 304 (1948). This is the same Briggs case in which the Supreme Court laid down the rule that a lower court could not use $\$ 1961$ to add interest to a judgment entered after an appeal. See text at notes 45-54 supra. The Supreme Court, however, refused to rule on the second circuit's construction of $\$ 1961$. 334 U.S. at 307 .

The second circuit's position is also expressed in Murphy v. Lehigh Valley R.R., 158 F.2d 481. (2d Cir. 1946). Cf. Browne v. Makin, 177 F.2d 753 (5th Cir. 1949).

Only once has the Supreme Court specifically discussed whether or not $\S 1961$ allows pre-judgment interest. The answer, given as dictum, was that the statute "would seem to exclude the inference that interest should be allowed upon verdict before judgment." Massachusetts Benefit Ass'n v. Miles, 137 U.S. 689, 691 (1S91).

70. $142 \mathrm{~F} .2 \mathrm{~d} 847$ (5th $\mathrm{Cir}$. 1944). The following cases support this positiun: Wright v. Paramount-Richards Theatres, Inc., 198 F.2d 303, 308 (5th Cir. 1952); Givens v. MricuuriKansas-Texas R.R., 196 F.2d 905 (5th Cir. 1952); Equitable Life Assurance Soe'y v. Trimble, 83 Fed. 85 (9th Cir. 1897); Griffith v. Baltimore \& O. R.R., 44 Fed. 574 (C.C.E.D. Ohio 1890), aff'd without consideration of this point, 159 U.S. 603 (1895); Gunther v. Liverpool, London \& Globe Ins. Co., 10 Fed. $\$ 30$ (C.C.E.D.N.Y. 18S2), revid os other grounds, 116 U.S. 113 (1S85). And see United States v. Verdier, 164 U.S. 213 (1896) (semble).

71. Briggs v. Pennsylvania R.R., 164 F.2d 21, 23 (2d Cir. 1947), off'd acithout consideration of this point, 334 U.S. 304 (1948).

72. Ibid.

73. QUESTIONNAIRE. $2 S$ out of 35 clerks ( $80 \%$ ) reported that interest ran only frum judgment, 5 clerks $(14 \%)$ allowed interest from verdict, and the other 2 clerls $(6 \% \mathrm{c})$ appeared in doubt. 
The Pratt rule rests on an "equitable" construction of section 1961 to allow interest from the date the correct judgment should have bocn entered, and then invokes Federal Rule 58, ${ }^{74}$ which orders entry of juclgment in most cases immediately upon the verdict, ${ }^{75}$ to place the date this judgment should have been entered at the time of verdict. ${ }^{76}$ This application of the "equity of the statute" doctrine ${ }^{77}$ stems directly from an early Supreme Court case which held that a determination similar in quality to a judgment could bear interest under section 1961, since such a determination "occupied the same legal ground" as a judgment, and since there was an "equity" in the statute.78 Although the opinion did not suggest that the statute permits interest to run from any date prior to final judgment, ${ }^{79}$ two district courts subsequently relied on the "equity" doctrine to allow interest from verdict where judgment was delayed by lower court consideration of motions. ${ }^{80}$ The equity having thus

74. FED. R. Crv. P. 58.

75. FED. R. CIv. P. 58 exempts cases: (1) which involve multiple claims and where the adjudication is not final pursuant to FED. R. CIv. P. 54(b) ; (2) where there is a special verdict or a general verdict accompanied by answers to interrogatories; and (3) where the court directs judgment for relief other than money damages. In all other cases, the clerk is to enter judgment forthwith upon the verdict unless the court otherwise directs. Sce, generally, 6 MOORE, Federal Practice $\Uparrow 58.04$ (2d ed. 1953).

76. Louisiana \& Arkansas Ry. v. Pratt, 142 F.2d 847, 849 (5th Cir. 1944).

77. This doctrine has been used as a method of construing statutes in situations where the terms of the statute did not cover the precise facts of a case. In such instances, the doctrine suggests construing the statute to reach the result the draftsmen of the statute would probably have desired had they contemplated the facts of the case. For a complete discussion of the doctrine and its history, see Usatorre v. The Victoria, $172 \mathrm{~F} .2 \mathrm{~d} \mathrm{434,}$ 439-41 \& nn.12-16 (2d Cir. 1949). See also Loyd, The Equity of a Statute, 58 U. PA. L. Rev. 76 (1909). For a critical view of the doctrine, see Crawford, Statutory ConstriucTION § 179 (1940).

78. National Bank v. Mechanics' Nat'l Bank, 94 U.S. 437 (1876). For a detailed discussion of the case, see note 79 infra. Of the three other cases cited in Pratt on this point, two based allowance of pre-judgment interest on state law. Fowler v. Redficld, 9 Fcd. Cats. 620 , No. 5,003 (C.C.S.D.N.Y. 1882) ; Leitch v. Chesapeake \& O. Ry., 97 W. Va. 498, 125 S.E. 370 (1924). The third case, Griffith v. Baltimore \& O.R.R., 44 Fed. 574 (C.C.E.D. Ohio), aff'd without consideration of this point, 159 U.S. 603 (1895), rests ultimately on Mechanics' Bank, supra.

79. The case involved claims for interest on demand bank notes on which the defendant had defaulted but which it had later paid in installments. Plaintiff claimed interest from the date of demand for payment up to the date of payment of each installment of principal and, in addition, interest on this aggregate amount of interest from the date of the final payment of the principal. The court held plaintiff's claim to be equivalent in law to a judgment since the claim had been proved to the satisfaction of the comptroller of the currency, and that it therefore bore interest under $\S 1961$. To determine the amount of interest, the court applied state law and concluded that a judgment in New York would bear interest in the manner requested by plaintiff. The equity in $\S 1961$, however, was used only to equate the claim with a judgment and not to decide the time from which interest was to be allowed. National Bank v. Mechanics' Nat'l Bank, 94 U.S. 437 (1876).

80. Gunther v. Liverpool, London \& Globe Ins. Co., 10 Fed. 830 (C.C.E.D.N.Y. 1882), rev'd on other grounds, 116 U.S. 113 (1885) ; Griffith v. Baltimore \& O.R.R., 44 Fed. 574 (C.C.E.D. Ohio 1890), aff'd without consideration of this point, 159 U.S. 603 (1895). 
been discovered, the fifth circuit used it in Pratt to award interest from the date the plaintiff's judgment should have been entered had there been no judgment n.o.v. While the two earlier lower court decisions had emplojed the doctrine to allow interest from the date judgment should have been entered, Pratt applies it to allow interest from the date the correct judgment should have been entered. To reach this result, the Pratt rule uses the doctrine to accomplish a two-stage advancement of the starting date of interest. The first step is the elimination of the delay attributable to the lower court's error-the interval from erroneous judgment to correct judgment. Then rule 58 is used to avoid the delay occasioned by the trial court's consideration of motions-the period from verdict to erroneous judgment. $\$ 1$

Gunther also based allowance of interest in part on the defendant's fault in causing the delay. Griffith relied on all prior cases allowing interest from verdict, including those where the basis of interest was state law, defendant's fault, or the equity in $\$ 1961$. In Griffilh defendant insisted on paying the interest, while plaintiff contended he had no right to receive it. The amount of the verdict was $\$ 5,000$, and defendant was sceling to add prejudgment interest to place the amount in controversy over the jurisdictional minimum required for Supreme Court review. This factor clearly motivated the court's decision. "Where the law will sanction it, we should so apply it as to give the losing side an opportunity of review." 44 Fed. at 586. See also Equitable Life Assurance Soc'y v. Trimble, 83 Fed. 85 (9th Cir. 1897) (allowing interest from verdict to judgment, relying on Griffith).

81. In the Pratt case defendant had made a motion for a judgment n.o.v, which was granted by the trial court. The granting of the motion was then reversed by the fifth circuit on appeal, and on remand the district court entered judgment for the plaintifi with interest running from the date of judicial demand. Against defendant's chim that interest should run only from the date of entry of judgment for plaintiff, the fith circuit modified the lower court's judgment to allow interest from the date of verdict, using the theory set out in the text above. Louisiana \& Arkansas Ry. v. Pratt, 142 F.2d \&17 (5th Cir. 1944). Although the opinion in Pratt does not indicate when the lower court entered judgment n.o.v. for the defendant, the clerk of the district court has reported that the erroneous judgment was entered Oct. 23, 1942, nearly seven months after the verdict was rendered on March 31, 1942. Letter from Alton L. Curtis, Clerk, United States District Court, Western District of Louisiana, to the Yale Law Joumal, April 7, 1955, on file in Yale Law Library. Subsequently the Pratt rule became the subject of serious confusion when the fifth circuit held that where a defendant made a successful motion for judgment n.o.v. which was later reversed, plaintiff could receive interest on his judgment only from the day on which the trial court had granted the erroneous judgment for defendant. Givens v. Missouri-Kansas-Texas R.R., 196 F.2d 905 (5th Cir. 1952). Thus, if defendant made his motion on the same day the verdict was rendered, but it was not granted until sumetime afterward, plaintiff's interest would run from the later date rather than the date of verdict. This conflict with the Pratt holding may be reconciled by the fact that the Griess case involved a special verdict, which falls within one of the exceptions to rule 38 . See note 75 stipra. Nevertheless, to reach its result Gizins relied squarely on Briggs v. Pennsylvania RR, 164 F.2d 21 (2d Cir. 1947), which cannot be reconciled with the Prolt rule. Still later, in Wright v. Paramount-Richards Theatres, Inc., 198 F.2d 303 (5th Cir. 19\$2), the tiith circuit retreated from its position in Gizens. W'right involved another reversal of a judgment n.o.v. The court stated that the correct judgment should have been entered on a date which preceded the date of the lower court's erroneous judgment by nearly two munths, and consequently the court allowed interest from this earlier date. The date designated as the starting time of interest was in fact 18 days after the date the verdict was rendered but 
The fifth circuit's application of the equity of the statute doctrine to section 1961 achieves a desirable result. The allowance of interest from verdict is necessary to render the plaintiff whole where interest qua damages is considered to run only until verdict. ${ }^{22}$ The statute authorizes interest from a date which is generally the same as the date of the verdict. ${ }^{83}$ When entry of judgment in fact occurs some time after the verdict, the statute should admit of an equitable interpretation which provides for situations probably not contemplated by its draftsmen. ${ }^{84}$ Furthermore, Pratt adopts a thoroughly sensible approach in using rule 58 to place the starting date of interest at the date of verdict. In the first place, it seems certain that even when motions are pending, judgment can be entered at the date of verdict. Although there is opposing authority, ${ }^{85}$ this position is supported not only by the wording of

was nevertheless a date when defendant's motion was still pending. The clerk reports that the date used was the day the lower court ordered submission of briefs on the motion for judgment n.o.v. The decision appears to move towards the position taken in Pratl, but the reasoning is obscured because the court in Wright cites Givens as authority for the conclusion reached.

82. See text at note 37 supra. For cases in which interest qua damages was computed only up to the date of verdict, see note 67 sitpra.

83. Prior to the 1948 revision of the Judicial Code, $\$ 1961$ had authorized interest from "date of judgment." 28 U.S.C. \& 81.1 (1940). No apparent reason was expressed for the change to its present form which allows interest from "entry of judgment," the House Judiciary Committee commenting only that "changes were made in phraseology." H.R. Rep. No. 308, 80th Cong., 1st Sess. A166 (1947).

84. As a general rule, interest statutes, being in derogation of the common law, are strictly construed. E.g., Smith-McCord-Townsend Co. v. Camenga, 104 Colo. 7, 87 P.2d 751 (1939) ; Patten v. American Nat'1 Bank, 15 Colo. App. 479, 63 Pac. 424 (1900) ; Straus v. Elless Co., 245 Mich. 558, 562, 222 N.W. 752, 753 (1929). This rule is usually expressed, however, in a context other than one involving judgments. For example, Patten v. American Nat'l Bank, supra, construes an interest statute against a depositor stuing a bank, arguing that the equities do not favor adding interest qua damages to all the claims against the bank where doing so would give only slight benefit to each of the depositors. In the context of judgments, liberal construction has been allowed. E.g., Bashor v. Beloit, 20 Idaho 592, $119 \mathrm{Pac} 55$ (1911) (refusing to limit judgment-interest statute by statute prohibiting compound interest); Quinn v. Sigretto, 229 App. Div. 727, 241 N.Y.S. 835 (2d Dep't 1930) (allowing interest on judgment though interest claim not pleaded). Contra, Motyka v. Detroit, G.H. \& M. Ry., 260 Mich. 396, 244 N.W. 897 (1932).

85. "Had there been no pending motion to set aside the verdict judgment could, and should, have been entered forthwith but [by?] the clerk in accordance with the Rule 58... But after the motion was made it had to be decided before any judgment could be entered." Murphy v. Lehigh Valley R.R., 158 F.2d 481, 485 (2d Cir. 1946) ; Briggs v. Pennsylvania R.R., 164 F.2d 21 (2d Cir. 1947), aff'd without consideration of this point, 334 U.S. 304 (1948). See also Anderson v. Continental S.S. Co., 218 F.2d 84 (2d Cir. 1954); Voelker v. Delaware, L. \& W.R.R., 31 F. Supp. 515 (W.D.N.Y. 1939). The second circuit has never given any reason for this rule, which was first enunciated in Murphy. In fact, to support the rule Murphy cites only Louisiana \& Arkansas Ry. v. Pratt, 142 F.2d 847 (5th Cir. 1944). Yet in Pratt the fifth circuit said that under rule 58, "The date of the verdict and the date when the judgment should have been entered are the same in this case." Id. at 849 ; see discussion of Pratt at note 81 supra. And Pratt like Murphy involved delay from verdict to judgment caused by trial court consideration of defendant's motions. 
rule 58,86 but also by Federal Rule $62(\mathrm{~b}),{ }^{87}$ which provides for a stay of execution of judgment pending disposition of defendant's motions. ${ }^{88}$ This latter rule clearly contemplates that entry of plaintiff's judgment may properly be made before disposition of defendant's motions; otherwise there would be no need to stay execution. Secondly, although rule 58 allows a court to delay entry of judgment, 89 it seems preferable to avoid this delay whenever possible. Prompt entry of judgment upon the verdict avoids questions concerning the effective date of judgment liens, ${ }^{00}$ and this procedure prejudices neither side since the court can always stay execution if motions are pending. ${ }^{91}$ Thus, since the allowance of interest should be uniform, Pratt is correct to start the running of interest from verdict, the date at which judgment should be and usually is entered.

\section{Application of State Law}

Even if section 1961 is construed strictly, it is certain that if the prevailing state law allows interest from verdict to judgment, this state law applies to a federal judgment on a non-federal cause of action. ${ }^{92}$ The federal statute is then held applicable only to the post-judgment period, leaving an "unfilled field" prior to judgment in which state law may operate. The statutes of 24 states allow interest to be assessed from the date of verdict. ${ }^{83}$ In the other

86. "Unless the court otherwise directs ... judgment upon the verdict of a jury shall be entered forthwith by the clerk. ..." FEn. R. CIv. P. 58.

87. FED. R. CTr. P. 62(b).

88. See also Fed. R. Crv. P. 50(b).

89. FED. R. Civ. P. 58.

90. See 6 Moore, Federat Practice \{ 58.04[2], at 3516-17 (2d ed. 1953). Determination of the accrual date of judgment liens has obvious importance in bankruptcy cases where the lien is challenged as a preferential transfer made within four months of banliruptcy or as a judgment lien obtained within that period. See Bankruptcy Act $\S \S 60(a), 67(3), 30$ Star. 562, 564-65 (1898), as amended, 11 U.S.C. \$\$ 96, 107 (1952).

91. See note 87 supra and accompanying text.

92. "[Section 1961] does not exclude the idea of a power in the several States to allow interest upon verdicts, and where such allowance is expressly made by a State statute, we consider it a right given to a successful plaintiff, of which he ought not to be deprived by a removal of his case to the Federal court." Missachusetts Benefit Ass'n v. Mfiles, 137 U.S. 689, 691 (1891). For further authority see, e.g., Flaxon v. Stentor Co., 313 U.S. 487, 497 (1941) ; Moore-MIcCormack Lines, Inc. v. Amirault, 202 F.2d 893, 895-96 (1st Cir. 1953) (dictum); New Amsterdam Cas. Co. v. Soileau, 167 F.2d 767, 771-72 (5th Cir.), ecrl. denied, 335 U.S. 822 (1948) (relying on Louisiana law to grant interest from date of judicial demand to judgment).

93. Seven states allow interest on the verdict from the time it is rendered. Arrz. Conz ANN. \$34-128 (1939); Conn. Gen. Stat. \$ 8092 (1949); INd. A AnN. Stat. \$ 19-2002 (Burns 1950); MD. ANN. CODE GEN. LAws art. 26, § 17 (1951) ; R.I. GEN. LAws c. 4\$4, \$§ 1, 2 (1938); VA. CODE $\$$ \$-223 (1950); W. VA. CODE ANN. § 5653 (1949). Eleven states allow interest from verdict to judgment to be included in the judgment. CAL Cone Crv. Proc. $\S 1033$ (1953); Ill Ann. Stat. c. 74, § 3 (1935); Mfe Rev. Stat. c. 106, § 20 (1954); Mass. Ann. Laws c. 233, § 8 (1933); Mrce. Stat. ANn. $§ 19.4$ (1935) (applies only to actions in contract); Minn. Stat. ANn. $\$ 549.09$ (West 1946); Mlovit. Rev. Cones Aris. 
states, the case law is conflicting, with the result depending in part on the cause of the delay from verdict to judgment. If the delay is occasioned by a defendant's unsuccessful motion for new trial or for judgment n.o.v., most courts allow interest only from judgment. ${ }^{94}$ If the defendant's motion succeeds in the lower court but is reversed on appeal, the few decisions considering the interest problem conflict.95 If the defendant's motion is rejected only on condition that plaintiff remit part of his recovery, the courts also disagree,

§ 93-8622 (1947) ; N.H. Rev. Laws c. 396, § 1 (1942); N.Y. Civ. Prac. Act \$ 480; PA. Stat. Ann. tit. 12, § 781 (1953); Utah Code AnN. § 15-1-4 (1953). Five states allow interest from verdict to judgment as part of costs. Iowa Code ANN. $\$ 535.3$ (1950) ; N.C. GEN. STAT. § $24-7$ (1953) ; N.D. Rev. CODE § 28-2613 (1943) ; S.C. CODE § 10-1605 (1952); Wis. Stat. $\S 271.04(4)$ (1953). One state allows interest from date of judicial demand. La. Rev. Stat. Ann. $\$ 13: 4203$ (1951).

Cases decided under these statutes are cited at notes 94-98, 134-144 infra. The Rhode Island statute has been construed to suggest allowance of interest only from the date of final decision. Campbell v. Walsh-Kaiser Co., 78 R.I. 290, 81 A.2d 684 (1951); Gomes v. Orr \& Son, 78 R.I. 96, 79 A.2d 618 (1951) ; Zielonka v. United States Rubber Co., 77 R.I. 167,74 A.2d 246 (1950).

Twenty states allow interest only from judgment. Ala. CoDe tit. 9, $\$ 63(1940)$; Ark. Stat. Ann. \$ $29-124$ (1947) ; Colo. Rev. Stat. Ann. c. 73-1-2 (1953); Fla. Stat. Ann. $\S 55.03$ (1943); GA. Code ANN. § 57-108 (1953); IdAно CodE ANn. § 27-1905 (1948); Kan. Gen. Stat. § 16-204 (1949); Ky. Rev. Stat. § 360.040 (1953); Miss. Code AnN. $\S 39$ (1942) ; Mo. Ann. Stat. § 408.040 (Vernon 1951) ; Neb. Rev. Stat. \$ 45-103 (1952); Nev. Comp. Laws § 4322(c) (1929) ; N.M. Stat. Ann. \& 53-604 (1941); Ohro Gen. Cove ANN. \$ 8305 (1937); OKLA. Stat. ANN. \$ 15-274 (1938); Ore. Rev. Stut. \& 82.010 (1953); Tenn. Code Ann. § 7308 (Williams 1934); Tex. Rev. Civ. Stat. Ann. art. 5072 (1947); Wash. Rev. CODE $\$ 4.54 .110$ (1951); Wyo. Conp. Stat. Ann. $\$ 39-1103$ (1945). Four states, Del., N.J., S.D., and Vt., have no statute governing interest on verdicts or judgments. Cf. VT. Rev. Stat. $\$ \S 2127,2134$ (1947) (allowing interest and damages on affirmed judgment during period of stay of execution).

94. Hawley v. Barker, 5 Colo. 118 (1879); Cleveland Ry. v. Williams, 115 Ohio St. 584, 155 N.E. 133 (1926); State Automobile Ins. Co. v. Kaffenberger, 84 Ohio App. 304, 83 N.E.2d 916 (1948) ; Coulter v. General Fireproofing Co., 67 Ohio App. 71, 35 N.E.2d 1003 (1941); Carle v. Courtright, 69 Ohio App. 69, 40 N.E.2d 431 (1941); Kelscy v. Murphy, 30 Pa. 340 (1858) ; Kiessling v. N.W. Greyhound Lines, 38 Wash. 2d 289, 229 P.2d 335 (1951.) ; Great Northern Ry. v. Washington Elec. Co., 197 Wash. 627, 86 P.2d 208 (1939). Contra, Degnan v. Young Bros. Cattle Co., 152 Kan. 250, 103 P.2d 918 (1940); Koontz v. Weide, 111 Kan. 709, 208 Pac. 651 (1922) ; Freemont, E. \& M.V.R.R. v. Root, 49 Neb. 900,69 N.W. 397 (1896) ; Daly v. Savage, 27 Ohio App. 133, 160 N.E. 881 (1927).

Where the delay is caused by the court, interest has been allowed from verdict. Stark v. McConnell, 22 Ohio Op. 123 (C.P. 1940); American Gypsum Co. v. L.S. \& M.S.R.R., 27 Ohio Ct. App. (n.s.) 481 (1917).

Where the statute allows interest from verdict, it is uniformly followed. Golden Gatc Mill \& Mining Co. v. Hendy Mach. Works, 82 Cal. 184, 23 Pac. 45 (1889); Alpers v. Schammel. 75 Cal. 590, 17 Pac. 708 (1888); Reitz v. Yellow Cab Co., 248 Ill. App. 287 (1928) ; Cary v. Whitney, 50 Me. 337 (1863); Hodgson v. Phippin, 159 Mdd. 97, 150 Atl. 118 (1930).

95. Allowing interest from verdict: Noel's Adm'x v. Black's Adm'x, $244 \mathrm{Ky}, 655,51$ S.W.2d 955 (1932) ; Hilton v. State, 60 Neb. 421, 83 N.W. 354 (1900); Smith v. Am. Firc \& Cas. Co., 242 S.W.2d 448 (Tex. Civ. App. 1951).

Allowing interest only from final judgment: Milling Co. v. Buoy, 71 Kan. 293, 80 Pac. 
even in states with statutes allowing interest from verdict. In this situation, interest is allowed from either verdict, ${ }^{90}$ the date plaintiff elects to remit, or the entry of judgment on the unremitted amount. ${ }^{98}$ The reasons generally given by state courts for refusing interest from verdict are the strict wording of those statutes which allow interest only from judgment, ${ }^{09}$ and the theory that interest cannot be allowed until the amount of principal due is fixed. ${ }^{100}$ Allowance of interest from verdict is generally based on the defendant's fault in causing the delay in entry of judgment ${ }^{101}$ and on the desirability of fully compensating the plaintiff for the loss of use of his recovery. ${ }^{102}$ The latter reason is the only one which recognizes the function of interest on

591 (1905) ; Motyka v. Detroit, G.H. \& MI. Ry., 260 Mich. 396, 244 N.W. 897 (1932) ; \&f. Scullin v. Wabash R.R., 192 Mo. 6, 90 S.W. 1028 (1905).

Statutes allowing interest from verdict are uniformly followed. Bond v. United R.R., 159 Cal. 270, 113 Pac. 366 (1911) ; Lincoln Park v. Schmidt, 379 Ill. 130, 39 N.E.2d 1012 (1942) ; Salem Bedford Stone Co. v. Hobbs, 27 Ind. App. 604, 61 N.E. 956 (1901) ; Hobbs v. Thorns, 195 Va. 639, 79 S.E.2d 854 (1954); Stone v. First Nat'l Bank, 72 W. Va. 171, 77 S.E. 969 (1913).

96. States where statute allows interest from verdict: Weed v. Weed, 25 Conn. 494 (1857) ; Stever v. Associated Transp., Inc., 270 App. Div. 956, 63 N.Y.S.2d 006 (3d Dep't), aff'd, 296 N.Y. 674, 70 N.E.2d 169 (1946); Troetschel v. Pennsylvaniz Turnpike Comm'n, 42 Pa. D. \& C. 593 (1941); Sharp v. Keiser, 292 Pa. 142, 140 Atl. 772 (1928).

State with no judgment-interest statute: Erie Ry. v. Ackerson, 33 N.J.L. 33 (Sup. Ct. 1868).

97. States where statute allows interest from verdict: Borrow v. El Dorado Lodge, 75 Ariz. 218, 254 P.2d 1027 (1953) ; Rasmussen v. Milwaukee E.R. \& T. Co., 261 Wis. 579, 53 N.W.2d 442 (1952). See also Stever v. Associated Transp., Inc., supra note 96 (dissenting opinion).

98. State where statute allows interest from verdict: Dougherty v. Philadelphia Rapid Transit Co., 58 Pa. Super. 574 (1914).

State where statute allows interest from judgment: Sorenson v. Oregon Power Co., 47 Ore. 24, 82 Pac. 10 (1905).

99. E.g., Motyka v. Detroit, G.H. \& 11. Ry., 260 Mich. 396, 244 N.W. $\$ 97$ (1932); Coulter v. General Fireproofing Co., 67 Ohio App. 71, 35 N.E.2d 1003 (1941); Kiessling v. Northwest Greyhound Lines, Inc., 38 Wash. 2d 289, 297, 229 P.2d 335, 340 (1951) (alternative reasoning).

100. E.g., Borrow v. El Dorado Lodge, 75 Ariz. 21s, 220, 254 P.2d 1027, 1029 (1953); Stever v. Associated Transp., Inc., 270 App. Div. 956, 958, 63 N.Y.S.2d 603,609 (3d Dep't) (dissenting opinion), aff'd, 296 N.T. 674, 70 N.E.2d 169 (1946); Kiessling v. Niorthwest Greyhound Lines, Inc., 38 Wash. 2d 289, 297, 229 P.2d 335, 340 (1951) (alternative reasuning).

Refusal of interest from verdict has also been based on these reasons: the delay is "the law's delay," Hawley v. Barker, 5 Colo. 118 (1879) ; Kelsey v. Miurphy, 30 Pa. 340 (1858); the action is in tort, State Automobile Mlut. Ins. Co. v. Kaffenberger, S4 Ohio App. 304, 309,83 N.E.2d 916, 918 (1948); the verdict is "suspended" by the defendant's motion, Dougherty v. Philadelphia Rapid Transit Co., $58 \mathrm{~Pa}$. Super. 574 (1914).

101. Freemont, E. \& MI.V.R.R. v. Root, 49 Neb. 900, 914-15, 69 N.IW. 397, 402 (1896); Hilton v. State, 60 Neb. 421, 83 N.W. 354 (1900).

102. Daly v. Savage, 27 Ohio App. 133, 137, 160 N.E. $\$ 81$, $\$ \$ 2$ (1927) ; Erie R.R. v. Ackerson, 33 N.J.L. 33 (Sup. Ct. 1868).

Allowance of interest from verdict has also been based on the clerk's duty to enter judgment at date of verdict, Degnan v. Young Bros. Cattle Co., 152 Kan. 250, 258-59, 103 P.2d 918, 924 (1940) ; Koontz v. Weide, $111 \mathrm{Kan} .709,712-13,208$ Pac. 651, 653 (1922); and the 
judgments. ${ }^{103}$ To assure that interest fully compensates the plaintiff, all judgment-interest statutes should either be construed to allow interest from verdict, or be amended to require this result.

Where a cause of action is federally created, however, the majority view is that interest is a problem to be decided by federal law. ${ }^{104}$ Thus, state statutes and case law allowing pre-judgment interest are inapplicable. Where the cause of action is founded on a federal statute which specifically provides for interest on judgments, the terms of the statute are, of course, controlling. ${ }^{105}$ But usually the federal statute under which the action is brought has no provision for interest; in such cases section 1961 alone is held operative.

\section{From First Judgnent to Revised Final Judgment}

Delay from plaintiff's first judgment to revised final judgment generally occurs in cases which are appealed, since revisions of first judgments are usually made by appellate courts. In these cases, before a court considers whether section 1961 should be construed to allow interest during the delay, it must first decide whether the statute applies to the new judgment. While the Supreme Court's rationale in Briggs might lead to the conclusion that

theory that verdict renders the recovery liquidated, Noel's Adm'x v. Black's Adm'x, 244 Ky. 655, 658, 51 S.W.2d 955, 957 (1932).

103. See text at note 37 supra.

104. Louisiana \& Arkansas Ry. v. Pratt, 142 F.2d 847 (5th Cir. 1944); Briggs v. Pennsylvania R.R., 164 F.2d 21 (2d Cir. 1947) (alternative holding), aff'd zuithout consideration of this point, 334 U.S. 304 (1948) ; Murphy v. Lehigh Valley R.R., 63 F. Supp. 928 (E.D.N.Y. 1945), mod., 158 F.2d 481 (2d Cir. 1946); cf. Brooklyn Sav. Bank v. O'Neil, 324 U.S. 697, 715 (1945) (federal law held to exclude state law on question of interest qua damages) ; Murmann v. N.Y., N.H. \& H.R.R., 258 N.Y. 447, 180 N.E. 114 (1932) (same).

Contra, Louisiana \& Arkansas Ry. v. Pratt, supra at 849 (concurring opinion); City of Danville v. Chesapeake \& O. Ry., 34 F. Supp. 620 (W.D. Va. 1940); Fowler v. Redfield, 9 Fed. Cas. 620, No. 5,003 (C.C.S.D.N.Y. 1882) ; Leitch v. Chesapeake \& O. Ry., 97 W. Va. 498, 507, 125 S.E. 370,374 (1924) ; cf. T. \& M. Transp. Co. v. S. W. Shattuck: Chemical Co., 158 F.2d 909 (10th Cir. 1947) (state law relied on in part to award interest qua damages).

Both views are based on questionable authority. Exclusion of state interest laws is based on FELA cases in which the problem at issue forced the court to choose between mutually exclusive state and federal laws. For example, Louisiana \& Arkansas Ry. v. Pratt, supra at 849, relies on Toledo, St. L. \& W. R.R. v. Slavin, 236 U.S. 454 (1915) and St. L. S. F. \& T. Ry. v. Seale, 229 U.S. 156 (1913). Where interest is the litigated question, however, state statutes allowing pre-judgment interest can apply to judgments in federal causes of action without conflicting with a strictly construcd $\$ 1961$. See text at notes 71-73 supra. But application of state statutes has not been put on this ground. Instead, support is found in cases where interest is held generally to be a problem of local law. For example, Leitch v. Chesapeake \& O. Ry., supra at 507, 125 S.E. at 374, cites Massachusetts Benefit Ass'n v. Miles, 137 U.S. 689 (1891), which did not involve a federal cause of action.

105. Reed v. Howbert, 77 F.2d 227 (10th Cir. 1935) ; Mellon v. United States, 36 F.2d 609 (D.C. Cir. 1929). 
the statute may not be applied to any new judgments, ${ }^{100}$ the second circuit has correctly rejected this theory. ${ }^{107}$ Thus, it may be predicted that the Briggs rationale will not be interpreted to prevent the application of section 1961 to a final judgment which revises or replaces a plaintiff's first judgment. The question therefore arises whether the statute allows interest for the delay. This problem of construing the statute must also be faced where no appeal is taken, since in that event section 1961 clearly applies to new judgments. ${ }^{108}$ Revision without appeal can occur when a trial court amends its own judgment ${ }^{109}$ or rejects a motion for new trial only on condition that a remittitur be filed. ${ }^{110}$ As in the area of pre-judgment interest, authority for the allowance of interest from first to final judgment can be found in both section 1961 and in state law.

\section{Construction of Section 1961}

Courts generally allow interest for the period from first judgment to revised final judgment on the theory that the revision of the original judgment is a partial affirmance. ${ }^{111}$ Since section 1961 is held to apply to the first judgment, ${ }^{112}$ interest is allowed from first to final judgment on whatever part of the original judgment can be considered "affirmed" by the final judgment."13

106. See text at notes $45-54$ supra.

107. Chemical Bank \& Trust Co. v. Prudence-Bonds Corp., 213 F.2d 443 (2d Cir.), cert. denied, 348 U.S. 856 (1954). In Prudence the second circuit was reviewing a lower court's allowance of interest on a revised judgment entered in response to the second circuit's mandate. The mandate ordered the original judgment increased; no mention was made of interest on the original amount. The lower court had allowed interest on the tutal recovery from the date of the first judgment. On reappeal, the second circuit disallowcd the judgment-interest rate on the additional recovery prior to final judgment, but even though the mandate was silent as to interest on the original amount, the court anproved allowance of interest on this amount from the date of the first judgment. An extension of the Briggs rule would have prevented the lower court from adding any interest to the new judgment. See text at notes $45-54$ supra.

108. See cases cited note 10 supra.

109. See 6 Moore, Federal Practice \} 5 9 . 1 2 \text { (2d ed. 1953). }

110. Id. at [59.05[3].

111. E.g., Ex parte Republic of Colombia, 195 U.S. 604 (1904); Kneeland v. American Loan \& Trust Co., 138 U.S. 509, 511 (1S91) : "[I]n so far as the separate and distinct matters embraced in the former decrees were ordered to be incorporated into the new, it is to be regarded as pro tanfo an affirmance." Numerous state cases adopt this same rationale. See cases cited note 147 infra. But see De La Rama v. De La Rama, 241 C.S. 154 (1916), where the Supreme Court apparently based allowance of interest more on the lower court's discretion than on the effect of the higher court's affirmance.

112. See cases cited note 10 supra.

113. E.g., Chemical Bank \& Trust Co. v. Prudence-Bonds Corp., 213 F.2d 443 (2d Cir.), cert. denied, 34 U.S. 856 (1954) ; Harris v. Chicago Great Western Ry., 197 F.2d 829 (7th Cir. 1952).

This theory was not used in the Supreme Court cases cited at note 111 supra because those cases involved decrees in equity to which $\$ 1961$ was thought inapplieable. See nute 6 supra.

It should be noted that $\$ 1912$ has been held inapplicable in partial affirmance cases. See note 43 supra. 
Thus when a judgment is reduced, ${ }^{114}$ interest runs on the part which remains ;15 similarly, when a judgment is increased, ${ }^{110}$ interest runs on the amount of the first judgment. ${ }^{117}$ This theory has two limitations, however. First, in the case of increased judgments no interest is allowed on the additional amount of recovery, since this portion cannot be considered to have been affirmed. ${ }^{118}$ Secondly, the theory of partial affirmance has been restricted

114. A federal appellate court can reduce a recovery in thrce ways: (1) Reverse damage awards on separate counts or as to separate items. See, c.g., Colombia v. Cauca Co., 190 U.S. 524 (1903). (2) Affirm on condition that plaintiff file a remittitur. Sce, c.g., Texas Co. v. Christian, 177 F.2d 759 (5th Cir. 1949). (3) Reduce the amount of damages awarded by the lower court judgment. See, e.g., Harris v. Chicago Great Western Ry., 197 F.2d 829 (7th Cir. 1952). This third method is almost always limited to cases tried by the court without a jury, because change in a jury verdict would usually violate the constitutional right of trial by jury. U.S. Consr. AxEnd. VII, United States Potash Co. v. MeNutt, 70 F.2d 1003 (10th Cir. 1934). But reduction of a jury verdict is permissible where the jury has already determined the question of liability and there remains no factual issue as to damages, the excessiveness of the verdict being a matter of law. Sce, c.g., Garfield Aniline Works v. Zendle, 43 F.2d 537 (3d Cir. 1930). See, generally, 6 Moond, Federal Practice $\{159.05$ [3] (2d ed. 1953).

115. E.g., Ex parte Republic of Colombia, 195 U.S. 604 (1904); Kneeland v. American Loan \& Trust Co., 138 U.S. 509 (1891) ; Harris v. Chicago Great Western Ry., 197 F.2d 829 (7th Cir. 1952) ; cf. Globe Constr. Co. v. Brewer, 197 F.2d 707 (5th Cir. 1952).

116. A federal appellate court can increase a recovery in three ways: (1) Reverse the lower court's omission of damage awards on separate counts or as to separate items. See, e.g., Chemical Bank \& Trust Co. v. Prudence-Bonds Corp., 207 F.2d 67 (2d Cir. 1953), cert. denied, 347 U.S. 904 (1954). (2) Order a new trial unless defendant files an additur. (3) Increase the amount of damages awarded by the lower court. Sec, c.g., The Kia Ora, 252 Fed. 507 (4th Cir. 1918). Methods (2) and (3) are both limited to cases where there is either no jury or where the verdict is insufficient as a matter of law. Dimick v. Schicdt, 293 U.S. 474 (1935) (additur disallowed even though remittitur would have been permitted) ; Stentor Elec. Mfg. Co. v. Klaxon Co., 125 F.2d 820 (3d Cir. 1941), cert. denicd, 316 U.S. 685 (1942) (interest qua damages added to verdict). Both methods might be available even in cases with jury verdicts if the jury were not required by the seventh amendment. United States v. Kennesaw Mountain Battlefield Ass'n, 99 F.2d 830 (5th Cir. 1938), cert. denied, 306 U.S. 646 (1939). See, generally, 6 Moore, Federal Practice \59.05[4] (2d ed. 1953).

117. Chemical Bank \& Trust Co. v. Prudence-Bonds Corp., 213 F.2d 443 (2d Cir.), cert. denied, 348 U.S. 856 (1954).

118. Ibid. In Prudence the court did award interest qua damages at $3 \%$ on the increased part of the recovery from first to final judgment, but allowed the judgment-intercst rate of $6 \%$ to run on this amount only from final judgment.

Of course, an appellate court when increasing a lower court's award may order that interest run on the total amount of the final judgment from the date of the first judgment. In so doing, however, the appellate court is awarding interest in the exercise of its discretionary power to award proper relief, not deciding what $\S 1961$ allows. Coyle Lines v. United States, 198 F.2d 195 (5th Cir. 1952) ; Chesapeake \& O. Ry. v. Elk Refining Co., 186 F.2d 30 (4th Cir. 1950) ; Gotham Silk Hosiery Co. v. Artcraft Silk Hosiery Mills, Inc., 147 F.2d 209, 225 (4th Cir. 1945) ; The Kia Ora, 252 Fed. 507 (4th Cir. 1918); cf. Thorp v. American Aviation \& Gen. Ins. Co., 113 F. Supp. 764 (E.D. Pa. 1953), revd on other grounds, 212 F.2d 821 (3d Cir. 1954). But see Harrison v. Clarke, 182 F.2d 765 (8th Cir. 1910). See note 9 sipra. 
to cases where the appellate court revises a first judgment by the deletion or addition of whole items; for when the amount of a particular item is disputed on appeal, the revision of this "unliquidated sum" is not considered a partial affirmance. 119 Instead, the revised amount of the item has been viewed as an entirely new determination, replacing the original one. The item thus revised bears interest only from the entry of the modified judgment. 120

Both these limitations can be avoided, however, by use of the Pratt "equity of the statute" doctrine. ${ }^{121}$ Under this doctrine, section 1961 would allow: interest on the total amount of plaintiff's ultimate recovery for the interval from first to final judgment, since this final judgment should have been entered at the date the original judgment was in fact entered. This approach would be eminently sound. A revision of a first judgment is really a determination of the amount which the plaintiff should have received at the date of the original judgment. ${ }^{122}$ Whatever sum is finally declared to be due the plaintiff has been in the hands of the defendant from the date of the first judgment because of the trial court's error in rendering judgment for an incorrect amount. ${ }^{123}$ Upon rectification of the error, the benefit of possession should be transferred to the plaintiff. This result cannot be reached in many cases if the requirement that the sum be liquidated is applied. This criterion should be eliminated, since it bears no relation to the merits of plaintiff's right to prompt recovery of his judgment.124 And even where the revised amounts are liquidated, the theory of partial affirmance does not compensate plaintiff for the loss of use of an addition to his first judgment. ${ }^{125}$ Equitable

119. Damages for personal tort injuries is a typical example of an unliquidated item; a claim on a defaulted note where the only issue is validity of the instrument would involve a liquidated amount.

120. Harris v. Chicago Great Western Ry., 197 F.2d 829 (7th Cir. 1952). In Horris the seventh circuit was considering the allowance of interest on a judgment which the court had reduced by lowering the amount of one item for fees from $\$ 500,000$ to $\$ 350,000$. The court allowed interest on all other items of the first judgment from date of first judgment because "the obligation to pay interest upon this sum attached upon the entry of the District Court's judgment, which we affirm in this respect." Id. at \$36. But the court allowed interest on the $\$ 350,000$ only from the date of the lower court's revised final judgment because "neither the amount due for fees nor the due date of the obligation was authoritatively defined until our decision. There will be a final valid judgment only when a new one shall have been entered." Ibid.

121. See text at notes 74-81 supra.

122. See, e.g., Walker v. Gulf \& I. Ry., 269 Fed. 885,891 (5th Cir. 1921) ; Fellman v. Royal Ins. Co., 184 Fed. 577, 581 (5th Cir. 1911): "[T]here appears no reasen why we should not here render the judgment which the Circuit Court should have rendered."

123. See De La Rama v. De La Rama, 241 U.S. 154, 159 (1916): "But [the date of the lower court's first judgment] ... was the date at which but for the delays of the law the wife would have received her dues, the husband has had the use of the money meanwhile...."

124. Of course, this criterion could be eliminated by simply viewing the reduction of the unliquidated amount as a partial affirmance. Whatever sum is awarded by the final judgment was included in the first judgment, and the fact that the dollars were not identifiable would seem to be an absurd reason on which to base refusal of intercst.

125. See note 118 supra and accompanying text. 
construction assures full compensation in both situations. ${ }^{120}$ Furthermore, it offers a uniform solution to problems which are currently being solved by district court clerks in a variety of conflicting ways. ${ }^{\mathbf{1 2 7}}$

\section{Application of State Law ${ }^{128}$}

Since section 1961 regulates interest "from entry of judgment," the period from first judgment to revised final judgment is clearly within the scope of the federal statute. Therefore, it might be thought that section 1961 "fills the field" for this period. ${ }^{120}$ Nevertheless, state law has been applied, at least in non-federal causes of action, ${ }^{130}$ probably on the theory that since the federal statute applies the state rate applicable to post-judgment interest, it also invokes the state system of allowing post-judgment interest. ${ }^{131}$ Additional sup-

126. Full compensation is achieved because the interest on the judgment starts to run from the date to which the interest qua damages was computed. This date is normally the date of the first judgment. See note 37 supra and accompanying text. In the rare case where the appellate court revises a first judgment by adding an amount in excess of the verdict, see note 116 supra, it might compute interest qua damages on this increment up to the date of its own decision. Should this happen, interest on that part of the judgment comprised of this increment need run only from the date of the appellate court decision to assure full compensation. But if the court simply awards the sum which should have been included in the verdict and in doing so computes interest qua damages on the total recovery up to the date of verdict, then verdict should be the starting date for interest on the judgment.

127. Questionnarre. When the first judgment is reduced by the appellate court, 27 out of 32 clerks $(84 \%)$ allow interest on the remaining amount from the date of the first judgment, 1 clerk (3\%) from the date of the appellate court's mandate, 1 clerk (3\%) from the date of entry in the lower court docket of the appellate court's decree, and 3 clerlss (10\%) from the date of the lower court's final judgment. When the first judgment is increased, 23 out of 24 clerks (96\%) allow interest on the original amount from date of first judgment, while 1 clerk $(4 \%)$ allows interest on the original amount from the date of the appellate court's mandate. Eight out of 22 clerks (37\%) allow interest on the increased amount from date of first judgment, 6 clerks $(27 \%)$ from the date of the appellate court's mandate, 2 clerks $(9 \%)$ from the date of entry in the lower court docket of the appellate court's decree, and 6 clerks (27\%) from the date of the lower court's final judgment.

128. Resort to state law to allow interest from first to final judgment is necessary, if at all, only when a recovery is increased, or the amounts revised are unliquidated, since $\$ 1961$ itself allows interest on reduced amounts and on the original amount of an increascd recovery where all items are liquidated. See text at notes 111-20 supra. Nevertheless, state law may be relied on in other cases.

129. For discussion of the "filled field" theory in interest problens, see note $\mathbf{9 2}$ supra and accompanying text.

130. The problem whether or not state interest statutes apply to allow post-judgment interest in federal causes of action raises the same questions as the problem of pre-judgment interest. See note 104 supra. But see O'Riordan v. Nick F. Helmers, Inc., 84 N.Y.S.2d 92 (N.Y. City Ct. 1948), rev'd on other grounds, 195 Misc. 169, 88 N.X.S.2d 692 (Sup. Ct., App. T. 1949) (holding that the New York interest statute applies to the post-judgment period in an FLSA case even if it would not apply to the pre-judgment period).

131. While no case had made this argument explicitly, this rationale appears to be the only reasonable way to explain the following cases in which state law has been relied on to regulate post-judgment interest: United States v. West Texas Cottonoil Co., 155 F.2d 463 (5th Cir. 1946) (interest allowed on judgment for penalties because Texas statute 
port for the use of state statutes may be derived from the fact that the purpose of the federal statute was to bring state and federal courts into harmony on the subject of interest on judgments. ${ }^{132}$

State law is as much in conflict on post-judgment interest as it is on prejudgment interest. ${ }^{133}$ When the revision in the first judgment is caused by a remittitur, most courts allow interest from the first judgment, ${ }^{134}$ but some use the date the remittitur was ordered ${ }^{130}$ or the date of the final judgment. ${ }^{136}$ If the appellate court orders the first judgment reduced, a clear majority of courts allow interest from first judgment, ${ }^{137}$ although a few courts grant interest from the date of appellate court decision ${ }^{138}$ or the time of final

allows it) ; United States v. Henke Constr. Co., 68 F. Supp. 3 (WV.D. A10. 1946) (Missouri statute held to preclude interest after date of prevailing party's appeal); Water Co. of Tonopah v. Tonopah Extension Mining Co., 53 F.2d 653 (D. Nev. 1931) (interest on judgment held mandatory because of Nevada statute); People's Bank of Greenville v. Aetna Ins. Co., $76 \mathrm{Fed} .548$ (C.C.D.S.C. 1896) (interest disallowed on judgment for costs because of South Carolina statute); cf. Union Nat'l Bank v. Louisville, New Altany \& Chicago Ry., 163 U.S. 325 (1896); Harrison v. Clarke, 182 Fed. 765 (Sth Cir. 1910).

See Women's Catholic Order of Foresters v. Special School Dist, 105 F.2d 716, 722 (Sth Cir. 1939) : "The matter of interest in federal courts is controlled by the law of the state in which the federal court is sitting."

132. See Washington \& Georgetown R.R. v. Harmon's Adm'r, 147 U.S. 571, 586 (1893).

133. See text at notes 94-98 sipra.

134. United States Fidelity \& Guaranty Co. v. Mrillonas, 206 Ala. 147, 89 So. 732 (1921) ; Montgomery Light \& Water Power Co. v. Thombs, 204 Ala. 678, 87 So. 205 (1920); Arizona Eastern R.R. v. Head, 26 Ariz. 259, 224 Pac. 1057 (1924) ; Barnhart v. Edwards, 128 Cal. 572, 61 Pac. 176 (1900) ; Atlantic Coast Line R.R. v. Watkins, 99 Fla. 395, 126 So. 489 (1930) ; Piper v. Epstein, 326 Ill. App. 400 (1945) ; Grillis v. Patrick, 214 Miss. 747, 59 So. 2d 341 (1952); Start v. National Newspaper Ass'n 220 S.W. 870 (Mlo. Ct. App. 1920); Rawlings v. Anheuser-Busch Brewing Ass'n, 69 Neb. 34, 94 N.W. 1001 (1903); Waterman v. Chicago \& Alton R.R., 82 Wis. 613, 52 N.W. 1136 (1892); MrLimans v. City of Lancaster, 65 Wis. 240, 26 N.W. 566 (18S6).

135. Morris v. Standard Oil Co., 192 Cal. 343, 219 Pac. 998 (1923); Stolze v. St. Louis Transit Co., 122 Mio. App. 458, 99 S.W. 471 (1906).

136. Tennessee Elec. Power Co. v. Hanson, 18 Tenn. App. 542, 79 S.W.2d 818 (1934); Erwin v. Jones, 191 S.W. 1047 (Mo. Ct. App. 1917); Lehman v. Amsterdam Coffee Co., 151 Wis. 207, 138 N.W. 606 (1912).

137. Younis v. Hart, 59 Cal. App. 2d 99, 138 P.2d 323 (1943); Niles Sand, Gravel \& Rock Co. v. Míuir, 55 Cal. App. 539, 203 Pac 1009 (1921) ; Clark v. Dunham, 46 Cal. 204 (1873) ; Stephens v. Stephens, 300 Ky. 769, 190 S.W.2d 327 (1945) ; Waterbury v. Waterbury, 281 Ky. 107, 134 S.W.2d 1009 (1939) ; Hecker Products Corp. v. Transameriean Freight Lines, 296 Mich. 381, 296 N.W. 297 (1941) ; Laughlin v. Boatmen's Nat'l Banl, 354 Mo. 467, 189 S.W.2d 994 (1945); Roswell State Bank v. Lawrence Walker Cotton Co., 56 N.M. 107, 240 P.2d 1143 (1952) ; Hamilton v. Baltimore \& O. Ry., 22 Ohio Dee 80 (C.P. 1910) ; Brown v. Rogers, S0 S.C. 289, 61 S.E. $4 \div 0$ (1908); Gricbel v. Ruden, 62 S.D. 469, 253 N.W. 447 (1934) ; Falls County v. Mfires, 218 S.W.2d 491 (Tex Civ. App. 1949); Houston Gas \& Fuel Co. v. Perry, 127 Tex, 102, 91 S.W.2d 1052 (1936); Baum v. Daniels, 118 S.W. 754 (Tex. Civ. App. 1909).

138. Bolt v. Nelson, 263 Mich. 158, 248 N.W. 581 (1933); State ex rel. Dolenty v. Reece, 43 Mont. 291, 115 Pac. 681. (1911); Compton v. Hammond Lumber Co., 154 Ore. 650, 61 P.2d 1257 (1936). 
judgment. ${ }^{139}$ The few cases considering upward revisions either allow interest on the total amount of the final judgment from the date of the original judgment, ${ }^{140}$ or grant interest on the original amount from the time of first judgment and on the added amount from the date of appellate court decision. ${ }^{141}$ The results also vary where the case is reversed only as to some of the defendants, ${ }^{142}$ or remanded for decision of a question other than damages. ${ }^{143}$ Where reversal results in retrial of damages, however, it seems settled that interest runs only from final judgment. ${ }^{144}$ The principal reasons given for refusing interest from first to final judgment are that no interest can be allowed until the amount finally due is fixed, ${ }^{145}$ and that no interest can run on the first judgment because it was set aside or suspended by the revision. ${ }^{140}$

139. Maynard v. Maynard, 251 S.W.2d 454 (Ky. 1952); Beall v. Beall, 6 Ky. L. Rep. 516 (1885); Kinne v. Duncan, 323 Ill. App. 363, 55 N.E.2d 545 (1944); McGowan v. London \& Lancashire Ins. Co., 237 Ill. App. 561 (1925).

140. Beckman v. Skaggs, 61. Cal. 362 (1882) ; Livingston County v. Dunn, 300 Ky. 367, 190 S.W.2d 328 (1945) ; Deming Inv. Co. v. Giddens, 41 S.W.2d 260 (Tex. Civ. App. 1931); Anthony v. Warren, 28 Wash. 2d 773, 184 P.2d 105 (1947); cf. Curt Teich \& Co. v. LeCompte, 222 N.C. 602, 24 S.E.2d 253 (1943) (increase resulting from reversal of defendant's counterclaim).

141. Warner Constr. Co. v. Lincoln Park Comm'rs, 278 Ill. App، 42 (1934). See also Johnston v. Geary, 34 Wash. 524, 76 Pac. 258 (1904) (allowing interest on the total amount of the final judgment from date of appellate court decision).

142. Allowing interest from first judgment: Sebastian County Coal \& Mining Co. v. Mayer, 310 Mo. 104, 274 S.W. 770 (1925) ; Fairhaven Land Co. v. Jordan, 6 Wash. 551, 34 Pac. 142 (1893). Allowing interest only from final judgment: DeHart v. Continental Land \& Fur Co., 205 La. 569, 591, 17 So. 2d 827, 834-35 (1944); Hoclzel v. Chicago, R. I. \& P. Ry., 340 Mo. 793, 102 S.W.2d 577 (1936).

143. Allowing interest from first judgment: Pfrimmer v. Tidwell, 207 Okla. 605, 252 P.2d 123 (1952) (remand as to special tax problem); Rasmussen v. Milwaukee E.R. \& T. Co., 261 Wis. 579, 53 N.W.2d 442 (1952) ; Zeidler v. Goelzer, 191 Wis. 378, 211 N.W. 140 (1926) (remand on issue of liability). Allowing interest from appellate court decision: Zielonka v. United States Rubber Co., 77 R.I. 167, 74 A.2d 246 (1950). Allowing interest only from final judgment: Kennard v. Wiggins, 353 Mo. 681, 183 S.W.2d 870 (1944) (remand to make judgment effective) ; Buob v. Feenaughty Mach. Co., 4 Wash. 2d 276, 103 P.2d 325 (1940) (remand for findings by trial court).

144. Smith v. Clark, 38 Colo. 89, 88 Pac. 636 (1906); Roth v. Boies, 146 lowa 170, 124 N.W. 879 (1910); Coxsey v. Taylor, 201 Okla. 447, 209 P.2d 506 (1948); Nllen v. Hartford Acc. \& Indemnity Co., 190 Okia. 313, 123 P.2d 252 (1942); Wendt v. Fintch, 235 Wis. 220, 292 N.W. 890 (1940). But cf. Oliver v. Love, 104 Mo. App. 73, 78 S.W. 335 (1904).

Where the appellate court reversed defendant's successful motion to have plaintiff's judgment set aside, interest was allowed only from final judgment. Scullin v. Wabash R.R., 192 Mo. 6, 90 S.W. 1028 (1905). Cf. cases cited note 95 supra, involving reversal of defendant's successful motion for judgment n.o.v.

145. Morris v. Standard Oil Co., 192 Cal. 343, 356, 219 Pac. 998, 1003 (1923) ; Compton v. Hammond Lumber Co., 154 Ore. 650, 61 P.2d 1257 (1936); Buob v. Feenaughty Mach. Co., 4 Wash. 2d 276, 300, 103 P.2d 325, 337 (1940).

146. E.g., Erwin v. Jones, 191 S.W. 1047 (Mo. Ct. App. 1917) ; Stolze v. St. Louis Transit Co., 122 Mo. App. 458, 99 S.W. 471 (1906) ; Tennessee Elec. Power Co. v. Hanson, 18 Tenn. App. 542, 550-51, 79 S.W.2d 818, 823 (1934).

Refusal of interest has also been based on the fact that the prevailing party was the appel- 
Interest is awarded either because the first judgment is considered partially affirmed, ${ }^{147}$ or because the final judgment is held to be the amount which the plaintiff should have received at the date of first judgment. ${ }^{148}$ This last reason is the only one which relates to the function of interest on judgments. 140 In order that interest fully compensate the plaintiff, state judgment-interest statutes should always be construed to allow interest on a final judgment from the date of the first judgment unless the final judgment results from a retrial of damages.

\section{CoNCLUSION}

It is apparent that the basic consideration in resolving the problems of interest on judgments is full compensation of the injured party. Furthermore, it should be clear that interest on judgments will completely compensate the plaintiff only if it runs from the date to which interest qua damages has been computed. ${ }^{150}$ Defendants' basic objection to this formula challenges the allow-

lant. Three conflicting rules have been delveloped: (1) Interest runs gren though the suecessful plaintiff is the sole appellant. Mayor of Savannalr v. Champion, 54 Ga. 541 (1875); Hervey v. Bangs, 53 Me. 514 (1866) ; Schofeld v. Cleveland Trust Co., 38 Ohio Op. 392 (C.P. 1948). And where both parties have appealed. Reitz v. Yellow Cab Co., 248 IIl. App. 287 (1928) ; Hecker Products Corp. v. Transamerican Freight Lines, 296 Arich. 381,290 N.W. 297 (1941) ; Oliver v. Love, 104 11o. App. 73, 78 S.WV. 335 (1904) ; Stever v. Associated Transp., Inc, 270 App. Div. 956, 63 N.Y.S.2d 606 (3d Dep't), aff'd, 296 N.Y. 674, 70 N.E.2d 169 (1946). (2) Interest stops at the time plaintiff files his appeal. Mrilliken $\mathrm{v}$. Haner, 184 Ky. 694, 212 S.W. 605 (1919) ; State ex rel. Southern Real Estate \& Financial Co. v. St. Louis, 234 Mo. App. 209, 115 S.TV.2d 513 (193S). (3) Interest stops only if the plaintiff is the first party to file an appeal. Wisman v. Cleveland Ry., 32 Ohio Op. 525 (C.P. 1945) (alternative holding) ; Harden v. Harden, 191 Okla. 698, 130 P.2d 311 (1943).

These additional reasons have been cited to disallow interest from first judgment: remand was caused by plaintiff's fault in failing to join necessary parties, DeHart v. Continental Land \& Fur Co., 205 La. 569, 591, 17 So. 2d 827, 834-35 (1944), or in giving improper instruction, Hoelzel v. Chicago, RI. \& P. Ry., 340 MIo. 793, 797, 102 S.W.2d 577, 578-79 (1930); the delay was not the defendant's fault, MicGovan v. Londun \& Lancashire Ins. Co., 237 Ill. App. 561 (1925) ; or the judgment could not be collected until final judgment, Kennard v. Wiggins, 353 MIo. 681, 687, 183 S.IY.2d 870, 872 (1944).

147. E.g., Younis v. Hart, 59 Cal. App. 2d 99, 107, 13S P.2d 323, 327 (1943) ; Stephens v. Stephens, $300 \mathrm{Ky} .769,190$ S.W.2d 327 (1945) ; Laughlin v. Boatmen's Nat'l Banls, 354 Mo. 467, 477, 189 S.W.2d 974, 980 (1945).

148. E.g., Livingston County v. Dunn, 300 Ky. 367, 376, 190 S.WW.2d 328, 332 (1945); Falls County v. Mires, 218 S.W.2d 491, 496 (Tex. Civ. App. 19:9).

Allowance of interest from first judgment has also been based on the fact that defendant had the use of the recovery, Hamilton v. Baltimore \& O. Ry., 11 Ohio N.P. (n.s.) 437, 22 Ohio Dec 80 (1910); and on "reason and justice," Rawlings v. Anheuser-Busch Brewing Ass'n, 69 Neb. 34, 36, 94 N.IW. 1001, 1002 (1903); or on "the general rule" and "the equities," Waterbury v. Waterbury, 281 Ky. 107, 111, 134 S.W.2d 1009, 1011 (1939).

149. See text at note 37 supra.

150. It may be argued that interest on judgments is really a windiall and thereiore does more than render a wronged party whole. This appears to be true sinee the judgmentinterest rate is normally higher than the earning rate of money. For a collection of the various state judgment-interest rates, see Note, 44 HARv. L. REv. 105, 108-09 n.35 (1930). When not bound by a prevailing statutory interest rate, courts have not hesitated to con- 
ance of interest on judgments from any date before entry of correct final judgment. This argument regards interest as merely a charge for withholding money due. ${ }^{151}$ The general theory advanced to support defendants' position is that the delays in entering correct final judgments are "necessary in the sense that time for appellate reviews [is] required" and should therefore not be charged to the defendant. ${ }^{152}$ But this argument begs the essential question. Granting the existence of these delays, the real isste is who should bear the cost resulting from the loss of use of money. One party must, and since the defendant is the adjudged wrongdoer, this expense properly falls to him. Thus, interest should be allowed from verdict to payment. While this result can be achieved in some cases by application of state laws, the method which most uniformly accomplishes the task is to apply section 1961 with the equity of the statute doctrine so that interest runs on every judgment from the date the correct judgment should have been entered.

demn as excessive the $6 \%$ rate usually allowed by judgment-interest statutes. This occurs frequently when courts allow interest qua damages on a claim up to the date of judgment. Rates from $4 \%$ to $2 \mathrm{r} / 2 \%$ have been used. See, e.g., United States v. Ring Constr. Corp., 209 F.2d 668 (9th Cir. 1954), affirming 113 F. Supp. 217 (D. Minn. 1953), and cases cited by the district court; Chesapeake \& O. Ry. v. Elk Refining Co., 186 F.2d 30 (4th Cir. 1950) ; United States v. United States Drill \& Tool Corp., 183 F.2d 998 (D.C. Cir. 1950).

The apparent excessiveness of the judgment-interest rate may be illusory. It should be noted that when interest is allowed from the date of the loss until payment, only one compounding is generally permitted-namely, the inclusion of interest qua damages in the interest-bearing judgment. See note 4 supre and accompanying text. But if the plaintiff had received his money at the date of his loss, he could have compounded it at least yearly and probably more frequently. Since interest should provide the real equivalent of the loss of use of the recovery, the judgment-interest rate is thus properly set somewhat above the money market. If it is still considered too high, adjustment should be made in the interest rate, not in the period to which the rate applies.

151. See cases cited note 145 supra.

152. See Chemical Bank \& Trust Co. v. Prudence-Bonds Corp., 213 F.2d 443, 445 (2d Cir.), cert. denied, 348 U.S. 856 (1954); Briggs v. Pennsylvania R.R., 164 F.2d 21 (2d Cir. 1947), aff'd without consideration of this point, 334 U.S. 304 (1948). 